УДК 314.74

\title{
Socialization of Tajik Students \\ in Tomsk University Space: \\ Looking for Models and Meaning
}

\author{
Nikolay P. Pogodaev* \\ National Research Tomsk State University \\ 36 Lenin, Tomsk, 634050, Russia
}

Received 05.08.2015, received in revised form 17.11.2015, accepted 22.02.2016

In the last ten years, the number of students from Tajikistan studying at Tomsk universities has been steadily increasing. Statistics of the Ministry of Education and Science of the Russian Federation shows that this process is typical for a number of other Russian regions. Migrant students face the challenge of adaptation and enculturation in the host community. An important part of this process is getting a good command of the Russian language. Some of the graduates will stay in Tomsk or will move to other major cities of Siberia that attract migration processes and are the multimodal migration hosts. They will become Russian citizens, start their own families here. Treating these "new Russian Asians" not as migrants, but as a part of the civil society will strengthen the solidarity of the nation and will facilitate the solution of administrative problems. Successful social experience of university graduates will help to switch the Youth Bulge phenomenon - the pressure of a large number of young people in Tajikistan on the socio-economic situation in the country of origin and in the host community - to a positive track. Those who will be unable to successfully fit into the host community may experience at first symbolic, and then physical ghettoization. Disappointment and frustration may encourage them to seek "social justice" through participation in criminal groups and radical religious organizations. Individual in-depth interviews, which are the primary method of gathering information in the framework of this research project, are considered in terms of the status and other attributes of the interaction between a respondent and an interviewer.

Keywords: migrant students, cultural distance, culture shock, migration capital, linguistic capital, Youth Bulge, new Russian Asians, individual in-depth interview.

The article was written within the framework of the project "A Man in the Changing World. Problems of Identity and Social Adaptation in the History and Modernity" (grant of the Russian Government $\Pi$ 220 No. 14.B25.31.0009).

Acknowledgements: I would like to express my appreciation to Elena Shakmareva for her valuable assistance.

DOI: 10.17516/1997-1370-2016-9-4-868-903.

Research area: sociology, culture studies.

\footnotetext{
(C) Siberian Federal University. All rights reserved

* Corresponding author E-mail address: nik-pogodaev@yandex.ru
} 


\section{Introduction}

Tomsk is the oldest University centre in Siberia, though nowadays it does not attract migration processes and does not serve as the multi-mode host of migration. The main and only notable component of the international migration here is student migration, including students from Central Asia. Upon graduation from Tomsk universities international students have to make a choice, whether they should return to Tajikistan or stay in Russia and integrate into the multimodal migration hosts. In Siberia these are, first of all, Novosibirsk, Krasnoyarsk, Irkutsk and Tyumen. There they will occupy certain niches in accordance with their education and abilities to fulfill their social demands. Herewith, this article introduces a new term, "new Russian Asians". We apply this term in relation to the people from the Central Asia, who have graduated from universities in modern Russia, stayed here to work and who claim to enter middle- or upperclass levels of the society and to have an access to the deficit resources in the economic, political and social spheres.

Adaptation of students from Tajikistan in Russian university societies is only one aspect of major problems of interaction between cultures and countries, adaptation of the host community not only to the increasing flow of migrants, but also to the gradual expansion of the ethnic and linguistic diversity of Siberia, growth of the Islamic Ummah.

Since 2006, studentmigration from Tajikistan to Tomsk and other university centers of Western Siberia and Russia as a whole has been increasing. This trend is the result of a deliberate policy of the two states in the field of education, actively supported in Russia at the regional level. Those who come to study in Russia today, were born in the sovereign Republic of Tajikistan, which has been gradually getting more and more different from the Tajik Soviet Socialist Republic of the
Soviet Union. Although many countries of the CIS are referred to as a part of the common cultural space, in reality the situation is quite different. Russia hosts young people from Tajikistan who have grown up in a different culture and therefore face the challenge of adaptation to the host community culture. One of the most important components of the Tajik students adaptation is studying the Russian language - verbal, written and professional slang of the chosen specialization - as a means of immersion in the culture of the host community with a certain prospect of further socialization. Tajik-Russian bilingualism, which was formed when the Tajiks became the part of the Russian Empire and the Soviet Union, has been undergoing significant changes recently. The current generation of young people know Russian worse than the older generation of the country. After graduating from Russian universities, migrant students will face a choice whether they return to Tajikistan or stay in Russia and become a part of its civil nation or live here in an ethnic ghetto. The basics of these future models are being already created when the current generation of students from Tajikistan enter Russian universities.

The basis of the research project are the materials of the author's individual in-depth interviews with the students from Tajikistan studying at universities of Tomsk, the leaders of the Tajik diaspora of the city, the Tajiks living in other cities of Russia, staff members of Tomsk universities and other representatives of the host community. Materials of the interviews are quoted maintaining lexical and grammatical features of the respondents' speech. This is another aspect of the case study method - an opportunity to show the degree of proficiency in Russian demonstrated by Tajik students of Tomsk universities. (Pogodaev, N.P. Strategiia ..., 2015).

We used a wide range of theoretical approaches to the analysis of the dynamics of 
cultural distance between peoples as a common methodological basis of research. In this article, the theory of "the social field" of the French sociologist Bourdieu and the thesis of the German sociologist Gunnar Heinsohn on Youth Bulge a malignant demographic priority of young people - are prioritized.

\section{Student migration \\ from Tajikistan: \\ tendencies and loci}

Since 2006, according to the data as of October 01, the universities of Tomsk had the following amount of students from Tajikistan: (Osnovnye rezul'taty...2015) (Table 1).

The inflow of students from Tajikistan in Tomsk universities rises the issue of the scale of the problem, other loci for training of specialists from this country. This information can be obtained at the website of the Ministry of Education and Science of the Russian Federation since the 2013/2014 academic year (Ministerstvo ...2014). The data of the Ministry allow to compare the amount of students from this country for the last two years (Ministerstvo ...2014) (Table 2, 3).
The largest amount of students from Tajikistan study in Moscow and Saint Petersburg (Table 4)

In the subjects of Siberian Federal District, students from Tajikistan are distributed as follows (Table 5).

Therefore, according to the data of the Ministry of Education and Science, in 2014 and 2015 Tomsk universities occupied the fourth place in Siberian Federal District by the amount of students from Tajikistan.

Regarding other federal districts, the article contains the information only for the subjects of the Russian Federation, where there are 100 and more students from Tajikistan studying at universities (Table 6-12).

From the above given data we can see that students from Tajikistan study throughout Russia. The major amount of students study in two capital cities, at universities of Central Russia, Volga region, Ural region and Siberia. It is obvious that the mass labour and student migration from Tajikistan to Russia has been caused by a whole set of factors, including historical ties between two countries, significant difference in the level of development of economics and the level of life and great difference in the demographic potential

Table 1

\begin{tabular}{|l|c|c|c|c|c|c|c|c|c|c|}
\hline \multicolumn{1}{|c|}{ University } & 2006 & 2007 & 2008 & 2009 & 2010 & 2011 & 2012 & 2013 & 2014 & 2015 \\
\hline Tomsk State University (TSU) & 2 & 5 & 13 & 10 & 19 & 16 & 21 & 20 & 28 & 46 \\
\hline $\begin{array}{l}\text { Tomsk Polytechnic University } \\
\text { (TPU) }\end{array}$ & 4 & 7 & 8 & 11 & 7 & 7 & 8 & 12 & 12 & 22 \\
\hline $\begin{array}{l}\text { Tomsk University of Control } \\
\text { Systems and Radioelectronics } \\
\text { (TUSUR) }\end{array}$ & 1 & 1 & 1 & 2 & 6 & 21 & 12 & 9 & 14 & 13 \\
\hline $\begin{array}{l}\text { Tomsk State University of } \\
\text { Architecture and Building } \\
\text { (TSUAB) }\end{array}$ & 0 & 0 & 0 & 0 & 0 & 14 & 39 & 28 & 36 & 31 \\
\hline $\begin{array}{l}\text { Tomsk State Pedagogical } \\
\text { University (TSPU) }\end{array}$ & 2 & 1 & 0 & 0 & 1 & 1 & 12 & 57 & 115 & 158 \\
\hline $\begin{array}{l}\text { Siberian State Medical } \\
\text { University (SibSMU) }\end{array}$ & 0 & 1 & 1 & 1 & 1 & 2 & 2 & 3 & 3 & 5 \\
\hline Total & 9 & 15 & 22 & 24 & 34 & 61 & 94 & 129 & 208 & 275 \\
\hline
\end{tabular}


Table 2

\begin{tabular}{|l|c|c|}
\hline & 2014 & 2015 \\
\hline $\begin{array}{l}\text { Total amount of students from Tajikistan in Russian higher } \\
\text { educational institutions }\end{array}$ & $\mathbf{8 , 7 7 7}$ & $\mathbf{1 1 , 7 3 1}$ \\
\hline Funded from the Federal budget & 3,525 & 5,146 \\
\hline On the basis of agreements on fee-based educational services & 5,212 & 6,517 \\
\hline Intramural study & $\mathbf{5 , 7 0 9}$ & $\mathbf{8 , 3 6 6}$ \\
\hline Funded from the Federal budget & 3,368 & 4,935 \\
\hline On the basis of agreements on fee-based educational services & 2,302 & 3,365 \\
\hline Extramural study & $\mathbf{2 , 8 0 0}$ & $\mathbf{3 , 0 4 9}$ \\
\hline Funded from the Federal budget & 128 & 170 \\
\hline On the basis of agreements on fee-based educational services & 2,675 & 2,877 \\
\hline Intramural-extramural study & $\mathbf{2 6 8}$ & $\mathbf{3 1 6}$ \\
\hline Funded from the Federal budget & 33 & 41 \\
\hline On the basis of agreements on fee-based educational services & 235 & 275 \\
\hline
\end{tabular}

Table 3

\begin{tabular}{|c|c|c|}
\hline & 2014 & 2015 \\
\hline Total amount of subjects of the Russian Federation & 84 & 84 \\
\hline $\begin{array}{l}\text { Amount of subjects of the Russian Federation where students from } \\
\text { Tajikistan study }\end{array}$ & 76 & 79 \\
\hline $\begin{array}{l}\text { Amount of subjects of the Russian Federation where } 100 \text { and more } \\
\text { students from Tajikistan study }\end{array}$ & 20 & 29 \\
\hline
\end{tabular}

Table 4

\begin{tabular}{|l|c|c|}
\hline & 2014 & 2015 \\
\hline Moscow & 1,002 & 1,131 \\
\hline Saint Petersburg & 740 & 798 \\
\hline
\end{tabular}

of both countries. Thus, according to the data of the International Monetary Fund, in 2014 Russia had 24,804 \$ per capita, and Tajikistan had 2,688 $\$$ per capita (the list of the countries by GDP). The birth rate as per 2014 data in Russia was 11.87 children per 1,000 people, in Tajikistan the birth rate was 24.99 children (Spisok stran po urovniu...)/ Nevertheless, there is another information about the level of birth in Russia in 2014, i.e. 13.31 children per 1,000 people (Estestvennyi...).

One of the methodological approaches to explain the emigration from the countries of Central Asia to Russia and other developed European countries is the concept of Youth Buldge used by the German sociologist Gunnar Heinsohn in his work "Sohne und Weltmacht: Terrorism, Aufstieg und Fall der Nationen" [Sons 
Table 5

\begin{tabular}{|c|l|c|c|}
\hline No. & \multicolumn{1}{|c|}{ Region } & $\mathbf{2 0 1 4}$ & $\mathbf{2 0 1 5}$ \\
\hline 1. & The Republic of Altai & 1 & 1 \\
\hline 2. & Altai Krai & $\mathbf{2 2 8}$ & $\mathbf{3 8 9}$ \\
\hline 3. & The Republic of Buryatia & 13 & 16 \\
\hline 4. & Zabaikalsky krai & 8 & 3 \\
\hline 5. & Irkutsk Oblast & $\mathbf{1 3 9}$ & $\mathbf{1 6 7}$ \\
\hline 6. & Kemerovo Oblast & $\mathbf{3 5 9}$ & $\mathbf{4 5 4}$ \\
\hline 7. & Krasnoyarsk Krai & $\mathbf{1 6 4}$ & $\mathbf{3 8 1}$ \\
\hline 8. & Novosibirsk Oblast & $\mathbf{2 1 7}$ & $\mathbf{2 5 9}$ \\
\hline 9. & Omsk Oblast & $\mathbf{1 7 5}$ & 20 \\
\hline 10. & Tomsk Oblast & 0 & $\mathbf{2 7 0}$ \\
\hline 11. & The Republic of Tyva & 6 & 0 \\
\hline 12. & The Republic of Khakassia & 1,322 & 4 \\
\hline 13 & Total for Siberian Federal District & 1,964 \\
\hline
\end{tabular}

Table 6. Central Federal District

\begin{tabular}{|c|l|c|c|}
\hline No. & \multicolumn{1}{|c|}{ Region } & 2014 & 2015 \\
\hline 1. & Voronezh Oblast & 202 & 211 \\
\hline 2. & Ivanovo Oblast & 352 & 304 \\
\hline 3. & Kostroma Oblast & 102 & 188 \\
\hline 4. & Moscow city & 1002 & 1131 \\
\hline 5. & Moscow Oblast & 177 & 142 \\
\hline 6. & Ryazan Oblast & 107 & 108 \\
\hline 7. & Tver Oblast & 62 & 123 \\
\hline 8. & Tula Oblast & 73 & 103 \\
\hline 9. & Yaroslavl Oblast & 241 & 295 \\
\hline
\end{tabular}

Table 7. Southern Federal District

\begin{tabular}{|c|l|c|c|}
\hline No. & \multicolumn{1}{|c|}{ Region } & 2014 & 2015 \\
\hline 1. & Rostov Oblast & 103 & 125 \\
\hline
\end{tabular}

Table 8. Northwestern Federal District

\begin{tabular}{|c|l|c|c|}
\hline No. & \multicolumn{1}{|c|}{ Region } & 2014 & 2015 \\
\hline 1. & Saint Petersburg & 740 & 798 \\
\hline
\end{tabular}


Table 9. Ural Federal District

\begin{tabular}{|c|l|c|c|}
\hline No. & \multicolumn{1}{|c|}{ Region } & 2014 & 2015 \\
\hline 1. & Sverdlovsk Oblast & 202 & 273 \\
\hline 2. & Tyumen Oblast & 146 & 321 \\
\hline 3. & Chelyabinsk Oblast & 77 & 104 \\
\hline
\end{tabular}

Table 10. Volga Federal District

\begin{tabular}{|c|l|c|c|}
\hline No. & \multicolumn{1}{|c|}{ Region } & 2014 & 2015 \\
\hline 1. & Republic of Bashkortostan & 92 & 176 \\
\hline 2. & Mari El Republic & 48 & 328 \\
\hline 3. & Republic of Mordovia & 1 & 155 \\
\hline 4. & Republic of Tatarstan & 325 & 601 \\
\hline 5. & Nizhny Novgorod Oblast & 142 & 146 \\
\hline 6. & Penza Oblast & 52 & 188 \\
\hline 7. & Samara Oblast & 210 & 359 \\
\hline
\end{tabular}

Table 11. Far Eastern Federal District

\begin{tabular}{|c|l|c|c|}
\hline No. & \multicolumn{1}{|c|}{ Region } & 2014 & 2015 \\
\hline 1. & Primorsky Krai & 89 & 121 \\
\hline
\end{tabular}

Table 12. North Caucasian Federal District

\begin{tabular}{|l|l|c|c|}
\hline No. & \multicolumn{1}{|c|}{ Region } & 2014 & 2015 \\
\hline 1. & Stavropol Krai & 66 & 149 \\
\hline
\end{tabular}

and World Domination: Terror in the Rise and Fall of Nations] (Heinsohn, G., 2003). Youth Bulge in terms of the German sociologist's work means a malignant demographic priority of youth. What is meant here is the comparison of the amount of men in the age of 40-44 with the amount of boys from 0 to 4 years old. "The demographic failure occurs when the amount of boys in the age from 0 to 4 years old per each 100 men in the age of $40-44$ is less than 80 "
(Khzmalian, T., 2015) Heinsohn provides the data that in Germany the ratio is $100 / 50$, in the Gaza Strip it's 100/464, in Afghanistan 100/403, in Iraq 100/351, in Somali 100/364. The main idea of the researcher from Bremen is that in the countries with the significant amount of young men in the structure of the population, there is an increase in conflicts obtaining different acute forms. Such demographic situation causes a multiplicative effect touching economic, social 


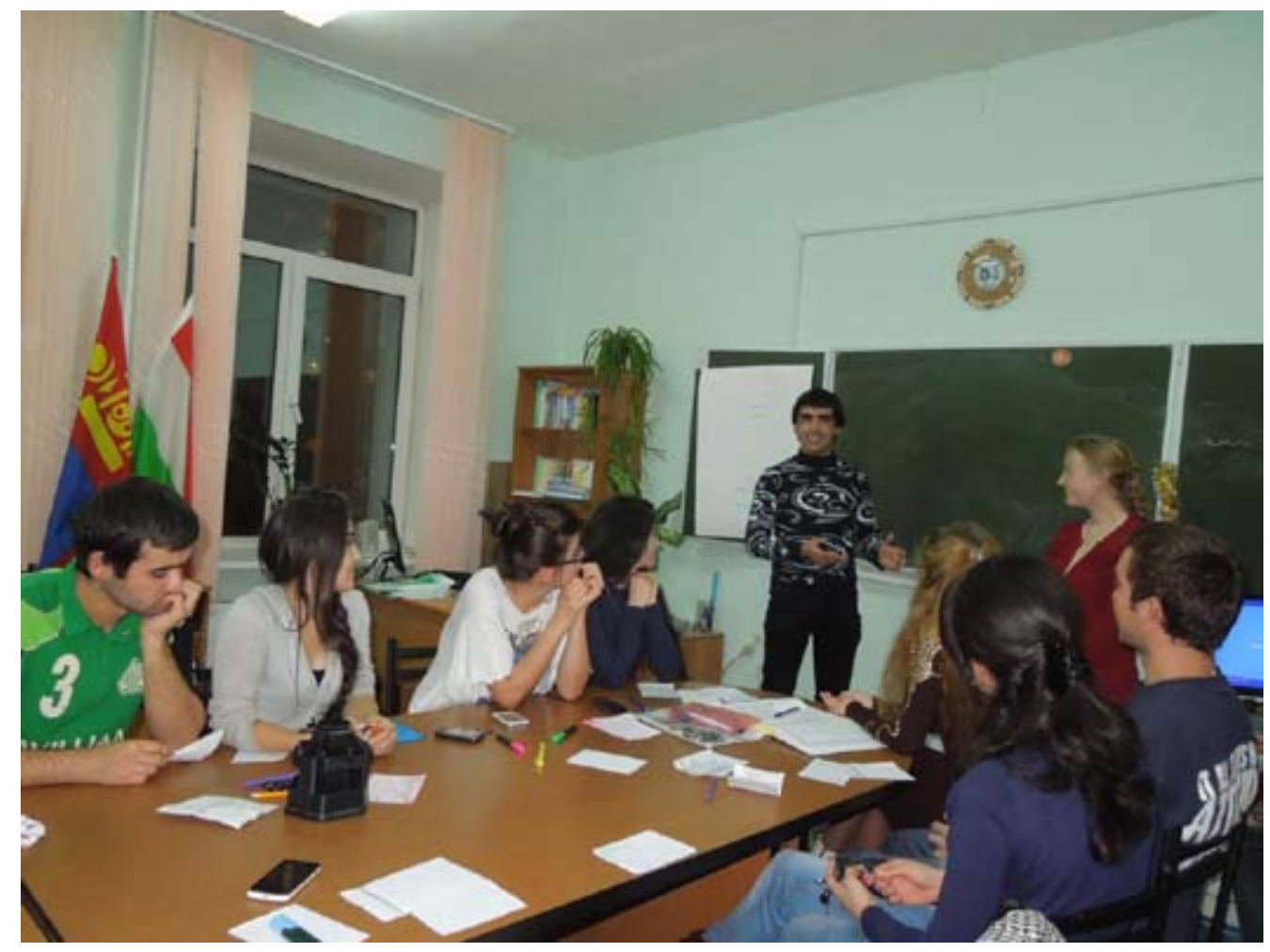

Fig. 1. Classes on social adaptation for Tajik and Russian students in one of Tomsk universities

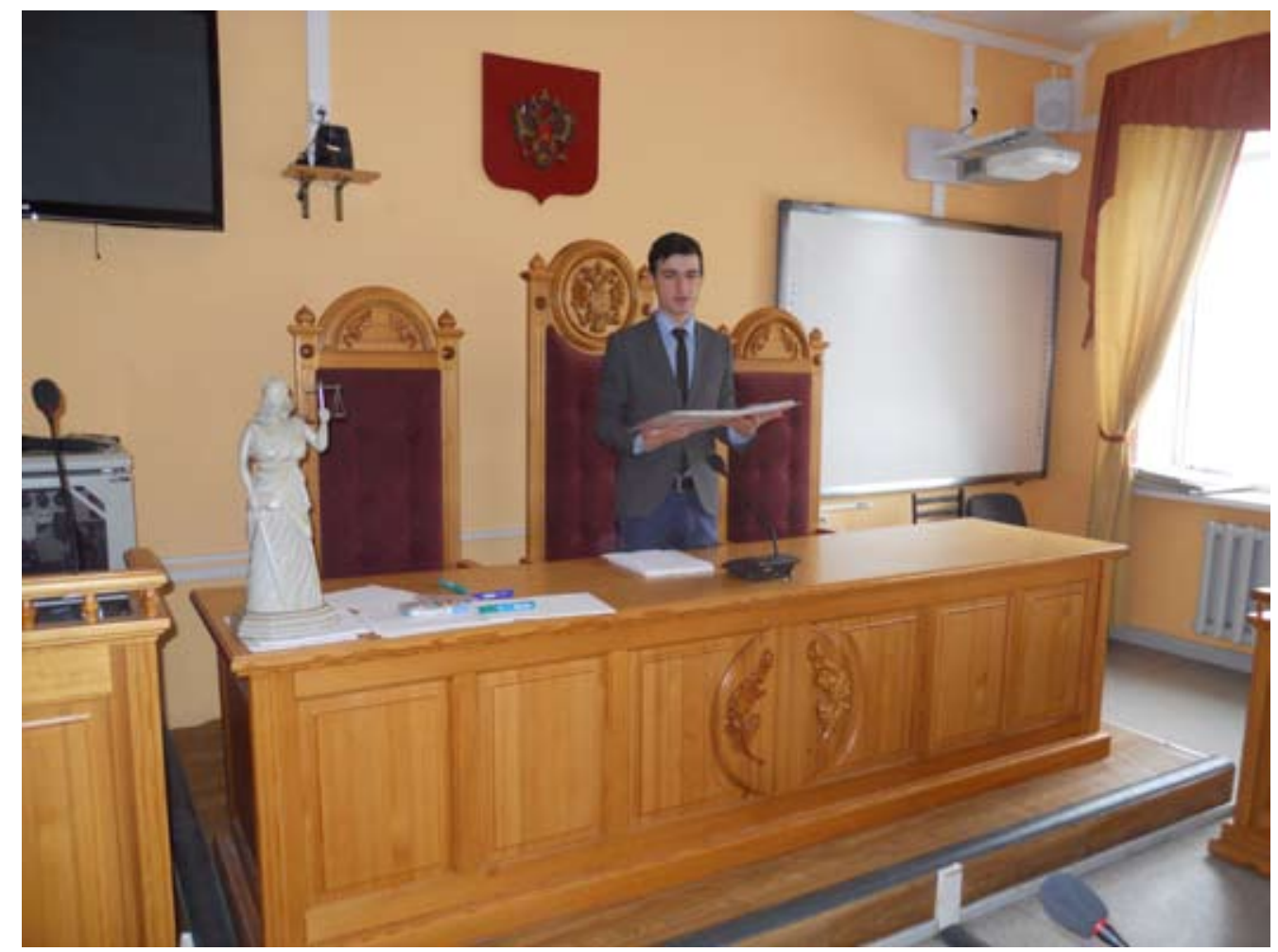

Fig. 2. A student of the Law Institute, Tomsk State University, in the court classroom 


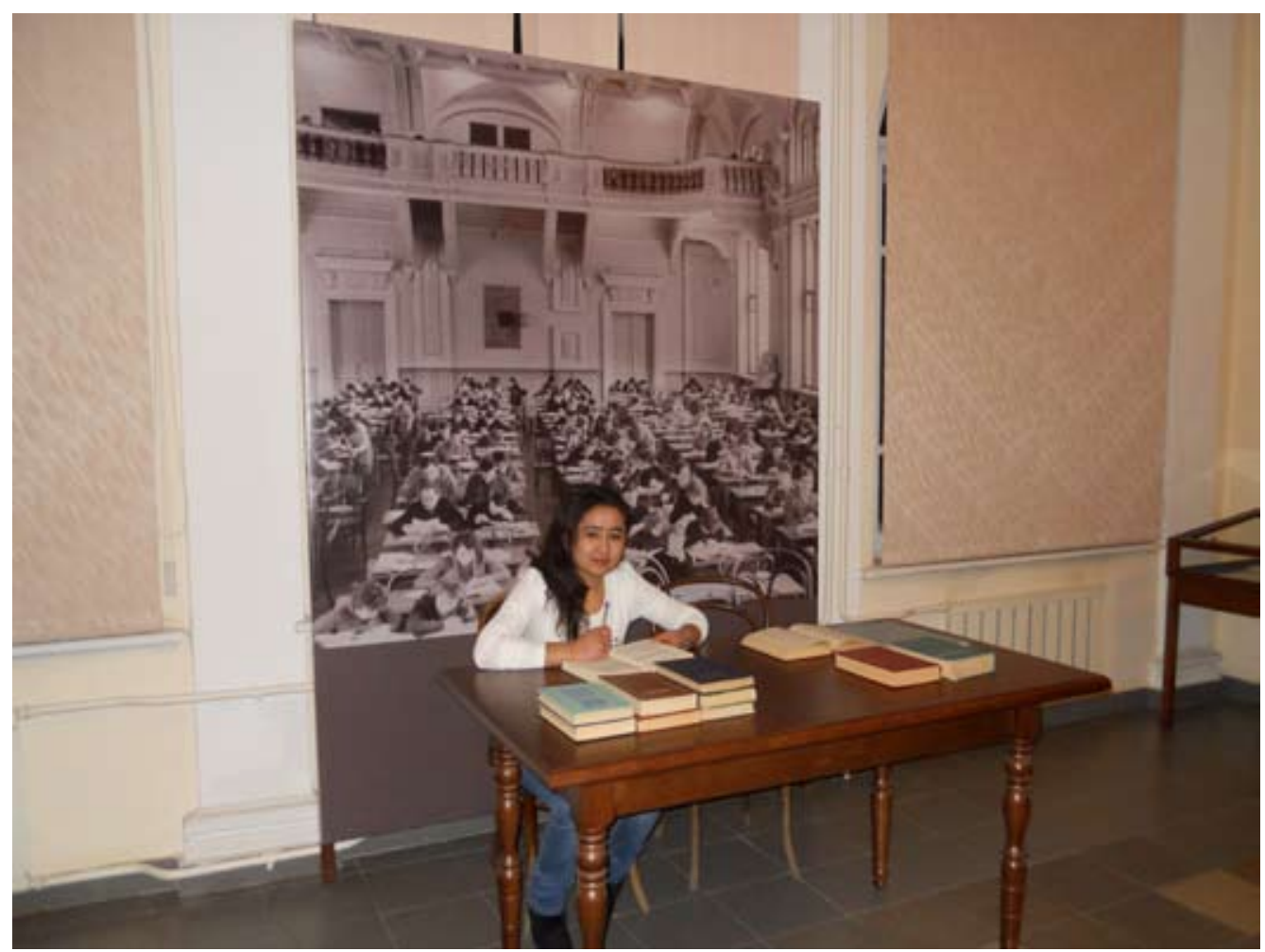

Fig. 3. The present on the background of the past: a panoramic photograph of the scientific library of the previous times behind the back of the law undergraduate student, when the previous generations of students from Tajikistan studied in TSU

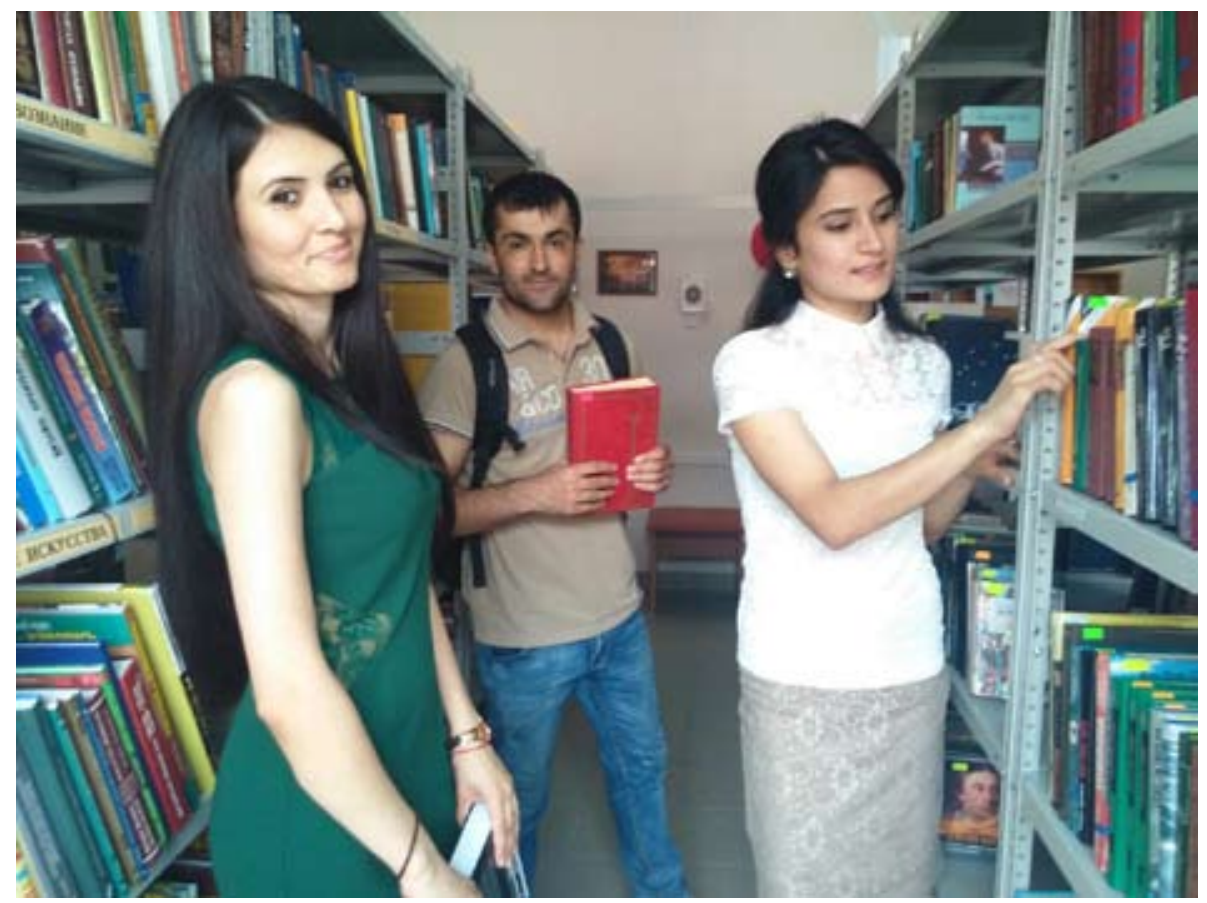

Fig. 4. The future of Tajikistan: upon graduation from Tomsk universities, a graduate student and two Master students will return home as high-level professionals 


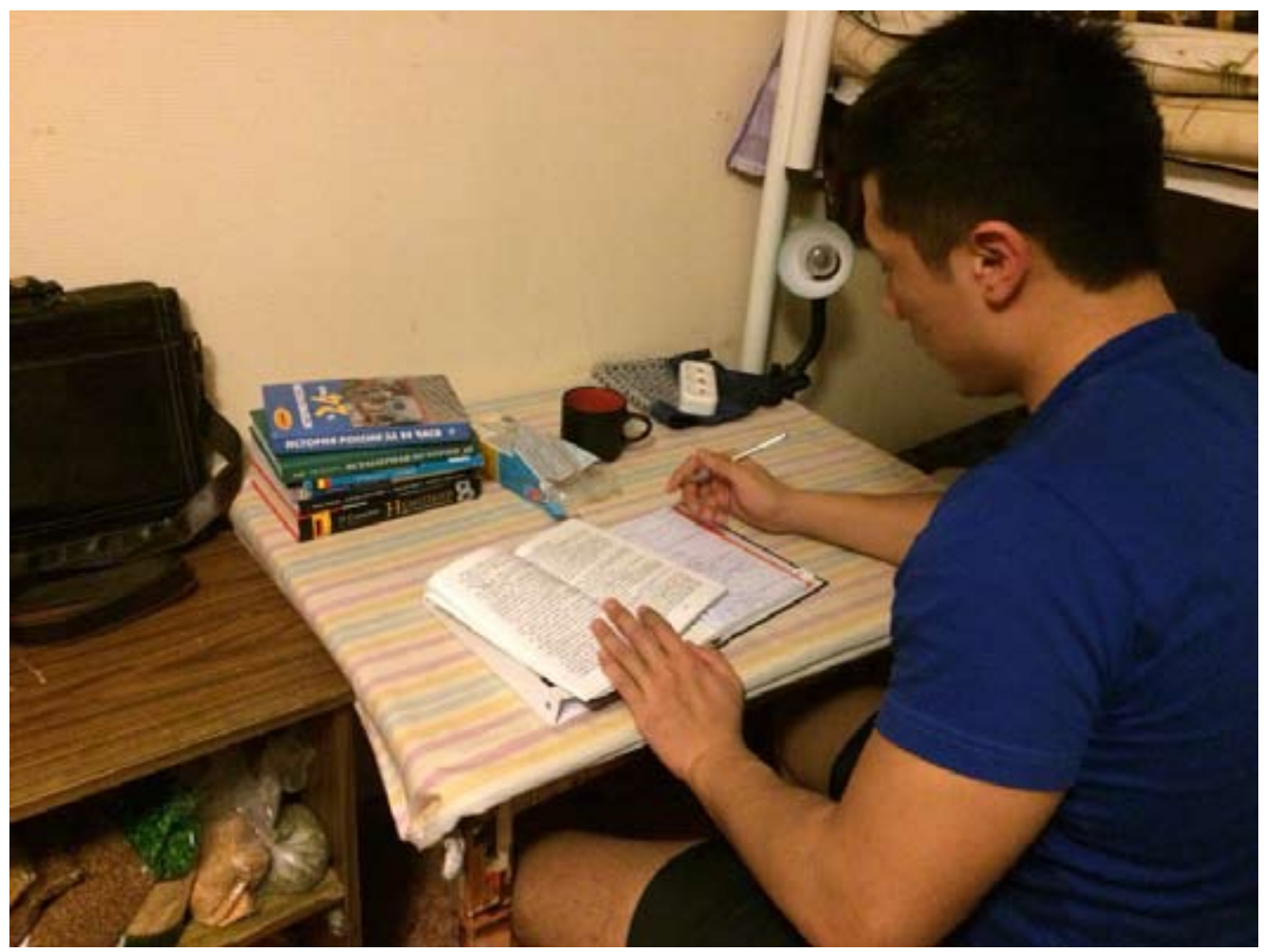

Fig. 5. Getting ready for the seminar on the history of Russia

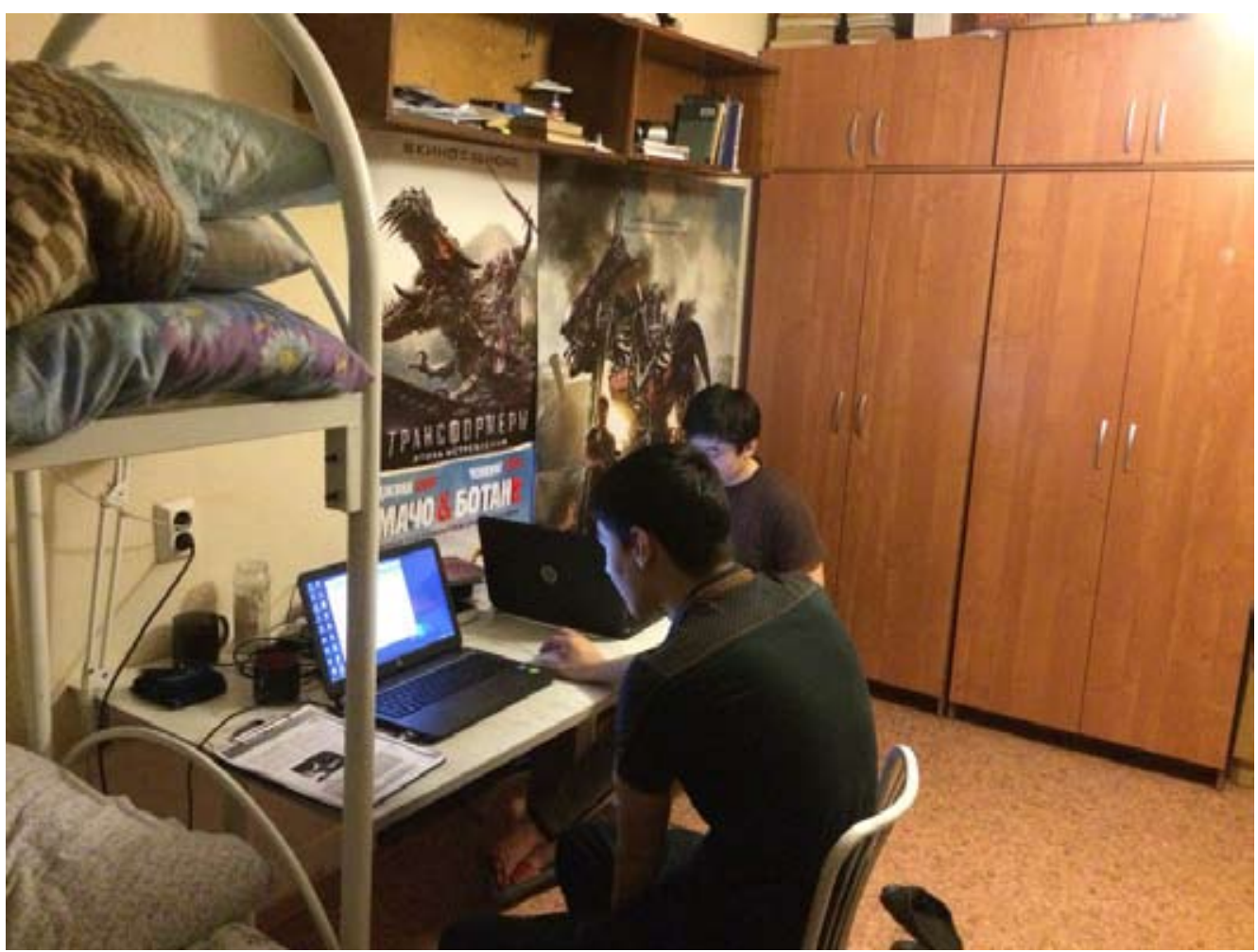

Fig. 6. Students from Tajikistan getting ready for classes in the room of the university dormitory 
and political spheres. One of the methods to solve this problem is emigration of the major part of young men. Countries where the amount of youth is insignificant, according to Heinsohn, cannot resist the rush of the young people from the countries with the excessive amount of youth. This aspect of the problem is being studied by international researchers (Beehner, L. 2007; Sophie Roche. 2014). This point of view, first of all, distinguishes age as one of important structural problems of the society, and secondly, allows to look at the labour and student migration through the prism of internal political safety of both the country of origin of the migrants and the host country. This raises the question, who young migrants from the overpopulated countries will become in the host community. Wherher they will become new physical and intellectual resource in the development of the host community and find a rightful place at the labour market, or they will join the marginal community layers, which tend to the parasitic attitude and aggression. Citing the words of the chief of one of the centers for socio-cultural and language adaptation of migrants in Krasnoyarsk, the attitude towards migrants from Central Asia has begun to change: "earlier the attitude was formed on the basis of multiculturedness, and now there is a trend of changing national stereotypes and integration of ethnophors into the host community"(Zapis'. Kruglyi stol. Arkhiv avtora).

\section{Preliminary Notes on the Research Methods}

In total, there are about 25 kinds of informants, who can in some way shed light on the process of student migration, as well as psychological and sociocultural adaptation of students from Tajikistan in Tomsk including staff members of the regional department on higher education of Tomsk Oblast Administration, staff members of universities, city residents of different social groups, chiefs and leading journalists of mass media able to give an expert evaluation of the problems of student migration in the host community. The information from the migration service institutions, insurance and medical institution working with migrant students is extremely interesting. The data of the Department of Internal Affairs of Tomsk Oblast and the Department of the Federal Service on Control of Illegal Turnover of Drugs can give a proof of a deviant behaviour of a certain migrant student and their violation of the host country laws or absence of such incidents. The information from public organizations dealing with the issues of inter-ethnic relations in Tomsk, real estate companies that migrant students can contact regarding renting issues, mosque attendants is quite interesting. The key information sources are the texts of agreements between the Russian Federation and the Republic of Tajikistan in the field of education, documents of Inter-Parliament Forums "Russia-Tajikistan" and other major public meetings between the representatives of both countries; books in schools of Tajikistan. Moreover, in this research there is information that the author obtained during participation in the Days of Education, Science and Culture of Tomsk Oblast in the Republic of Tajikistan on June 9-14, 2014, and during the work of the IV Inter-Parliament Forum "Russia-Tajikistan: the Potential of Interregional Cooperation" and III Conference on Interregional Cooperation of Russia and Tajikistan held in Moscow on October 23, 2014.

In addition to individual in-depth interviews, which will be discussed below, the study used the method of scouting (as defined by Gary Albrecht) (Knoblauch H., 2009), representing a number of procedures used for sensing of the research field. This method was used when entering the topic, when the author of this article was supervising the work of a first-year student from Tajikistan, 
who took up the analysis of the Tajik diaspora in Tomsk. Scouting was used during the work of the article's author as a member of the Tomsk Oblast delegation in Dushanbe. The intense schedule of meetings left no room for individual in-depth interviews, but visiting universities, communication with different representatives of the Tajik society, observations in the streets, shops and markets of Dushanbe allowed to get an idea of a number of processes taking place in Tajikistan, including the situation in the language field. Later, the scouting method was used in the process of communication with the teachers of the Pedagogical University in Krasnoyarsk. The purpose of the conversation was to clarify the scope of competences of specialists who participated in the conversation, and on this basis to determine the topics of the future individual in-depth interviews.

Individual in-depth interviews used as the main tool of collecting information about the process of adaptation of Tajik students in Tomsk, as any other methods, has its unconditional strengths and weaknesses. The good thing is a live conversation with a respondent, the ability to respond flexibly to certain thematic twists in the interview, to receive and take into account the characteristics of the respondent's personality, to record their reaction to certain issues raised in the conversation. Interviews provide an opportunity ask the respondent about the daily and their evaluation of certain events.

Nevertheless, we cannot ignore the latent problems of collecting information through this form of communication. The relationship of an interviewer and a respondent can be viewed through the prism of Bourdieu's concept of the social space. "The appropriated space, writes the French sociologist, is one of those places at which power is confirmed and executed, and that is in its doubtless most subtle form: symbolic violence as violence not perceived... as the etiquette of court societies, as curtseys and respect that is born from remoteness (e longinquo reverentia, according to Latin), more precisely, from mutual keeping at a distance" (Bourdieu, P. 1993, p.38). That is, a student from Tajikistan responding to the interview questions of an interviewer, a university lecturer, consciously or unconsciously makes "curtseys" regarding some issues based on the fact that he or she is not "at home", both in terms of the status and national-state relations. Similar interviews with Russian students from Russia and even Russian students from Tajikistan leave only a status distance, reduce the "alienation" and the number of such "curtseys". The art of interviewing is to try to avoid such questions that may lead to the distortion of the content information by bringing complementarity, and can provoke the respondent to take the comme il faut position (French: comme il faut. As it should be).

Just like "no ethnographic film is merely a record of another society: it is always a record of the meeting between a filmmaker and that society" (Pauwels, L. 2009), so a recorded individual in-depth interview is no absolutely reliable testimony of the respondent's world view. The interview is a meeting of two cultures with the inevitable omissions and bows on a number of issues. Therefore, we also do not consider the text of individual in-depth interviews as a record about the views of the respondent, but as a record of the meeting between the interviewer and the respondent in accordance with their statuses and other attributes of their interaction.

There is another important aspect of interaction between the interviewer and the respondent. The latter does not only get the information from the respondent, but in the words of the French anthropologist Jean Rouch, "stimulates mutual understanding" (Pauwels, L. 2009). Such stimulation can be more or less successful, effecting in a certain way the trust 
between the interviewer and the respondent and the frankness of the latter. The degree of the interviewer's awareness of the culture of the society of the respondent plays an important role. It was after the trip to Dushanbe, when the opportunity appeared to formulate the research problem more precisely, to develop the questions of the interview based herewith. It should be added that the stimulation of understanding can be performed not only by the interviewer, but by the respondent as well. That is, using Bourdieu's concept of social space, we can say that the respondent may seek a partial appropriation of the interviewer's space presenting them with their point of view on a certain controversial issue and convincing of the rightness of this viewpoint. This position is especially actualized when the respondent sees the interviewer as an essential channel to broadcast their views into the "social space of the interviewer". For example, during the interview with two influential representatives of the Tajik diaspora, I noticed that each of them was not just talking about their activities, but also consciously or unconsciously was trying to convince me of the rightness of their position, their actions and wrong behaviour of another leader. One of them, who has recently arrived in Tomsk from another Siberian region, said that he devoted a lot of time to solve the problems of students and migrant workers, to organize a Russian language course for them: «Невозможно было народ собрать, их (им - Н.П.) тетради купили, ручки купили, здесь всё плов сделали, тортик сделали, всё-всё, вот как-то...... Ми им первый, второй поток дали по 100 рублей стипендии. Лишь бы они пришли учились» [It was difficult to gather them together. We have bought them notebooks, pens, cooked rice pilaf, a cake, everything... We provided the first and the second course participants with 100 rubles of allowance, for them to study]. He talked about his strengths as the leader of the diaspora, while unlike his opponent, he hasn't got a strict schedule in the institution and has significant financial funds: «Bот, например, есть в городе вот... кто-то, кого-то (кто - Н.П.) диаспору содержит, какой-то определённый лич. Он бедный (руководитель диаспоры-Н.П.) от этого шаг не может выходить!.... Какой ты руководитель общества? Руководитель общества должен быть независимым человеком!» [For example, there is someone in the city, who finances the diaspora, a certain person. He (the leader of the diaspora - N.P.) is poor and in connection with this he cannot make a step! What kind of a leader is he? The leader of the society should be independent!]. He claimed that the leaders of the diaspora are not interested in the life of migrant workers coming to Tomsk : «...председатель и кто-то здесь ещё, аксакаль-максакаль, ни один человек не подходит, не спрашивает, ...двадцать два человека, «вы какой судьбы здесь попали?, что вам нужно?»[...the chairman and some else, aqsaqals-maqsaqals, none of them comes and askes ... twenty two people, 'What for have you come here? What do you need?'] (Interview TDT-4)

The representative of the opposing party blames the opponent in splitting the diaspora: «... Сегодняшний день существует ещё вторая организаџия, общественная организаџия, ... И вокруг него собрались как раз вот некоторые, которые...э.. в оппозиции $\kappa$ намей автономии... стоят. ... появление... второй организации, она дала ещё более вот этот..., глубже вот этот раскол» [... Today there is another organization, public organization... He gathered around him those.. eh... who are opposing our autonomy... Appearance of this second organization has caused this splitting... made it deeper]. The public organization that has been established recently is mainly used for promotion of commercial 
interests: «... в тендере когда участвует, либо там другие какие-то неприятности, ... он уже прикрывается общественной организацией. Либо, допустим, составит письмо поддержки со стороны населения от имени общественной организации ... И получается, карманная, в общем, это организация...» [When they participate in the tender process, and there are some troubles, they hide behind the public organization. Or, for example, he writes a letter of support from the population from this public organization... It appears that this organization is pocket-like]. He considers the above mentioned Russian language courses to be useless: «А обучение ничё не даст этим мигрантам. ... сертификат тоже ничё не даст, сертификат, допустим, приносят, покажут, что вот они проходили... - «Что, тыл проходил? замечательно, всё, вот садись, выполняй этот тест» (скажут сотрудники миграционной службы - Н.П.), тест не выполнил, всё, уже грош иена ... этому сертификату» [These courses are useless for the migrants. ... The certificate also is good for nothing. For example, they bring the certificate and show that they have taken a course... "Which course have you taken? Good, now sit down and complete this test" (the staff members of the migration service will say - N.P.). If they don't pass the test, the certificate is useless] (Interview TDT-6).

Both respondents perceived the interviewer (a university professor) as a representative of the host community, perhaps, capable of, in a certain way, transferring and interpreting the disputes in the Tajik diaspora. For them, apparently, it was very important at that time and, in their opinion, it contributed to the partial "appropriation" of the social space of the interviewer, as a representative of the host community. In this context, it can mainly concern either a purely academic space in which the study materials are actualized, or the space of the expert community, in which the author of the study may be claimed as an expert. Moreover, the disclosure of the information in the public space was considered possible. The interviewer thus obtained additional information about the processes that took place at that time in the Tajik diaspora.

The recording of the interview, of course, affects the interview. It has been explained to the respondents that the collected materials are anonymous, and none of them has been against the use of a recording device. However, in the course of the conversation they have sometimes mentioned the phrase "this is not for recording", thus pointing at the increased privacy of some information or a point of view. It is possible the respondents have preferred to omit some details when they saw the recorder turned on. That is the very culture of research is a part of the culture of interaction between the two cultures represented by the interviewer and the respondent. The fact that the researcher, as a result, receives the interview, is the result of interaction between the two cultures in the context of a specific research practice.

The situation of individual in-depth interviews can be described through a causal quaternium. The factors in its favour are the culture of the original community, the culture of the host community, the research culture and the meaningful goal setting of the research. It is the fourth factor that distinguishes the research interview (survey research) from the journalistic interview and interrogation by the investigator.

\section{Students from Tajikistan Developing Their Personal and Social "Migration Capital"}

We can consider the process of adaptation and enculturation of students from Tajikistan in the university space of Tomsk through Bourdieu's thesis about social space, which is the "abstract 
space constituted by an ensemble subspaces or fields ... the structure of which is due to the unequal distribution of certain types of capital ..." (Bourdieu, P. 1993, p.40). The principal subspaces of a foreign student are their presence in the native Tajik culture and presence in the Russian culture. They possess some capital with a quite dynamic potential (as well as any capital in general) within each of the subspaces. When getting ready for the trip to Russia, a prospective student is completely immersed in the realities of the space of their national culture. The capital in this space includes the native language, national mentality, national and family traditions, social networks of family and friends, religious views. With this national space capital on the background, Russia, of course, is perceived through the image of "the other".

The prospective student faces the space of the Russian culture in some kind of a virtual image based on the knowledge of Russia that they have obtained during their studies in the Tajik school (a certain level of the Russian language, information about Russian history, certain interpretation of interrelations of the Tajiks and the Russians in the historical retrospective), as a result of discussing the image of Russia and the Russians among family and friends, judging by the materials of the Tajik mass media and online TV programmes of the Russian mass media broadcasted in Tajikistan. Due to the traditions of Tajikistan, children's obedience to their parents, the prospective life and studies in Russia are also perceived through the pattern of their national culture coming from the family. Parents, as one of the respondents says, have said, «сынок, не натвори глупости там, чтобы у тебя до свадьбы детей не было. Это вообще стыд и срам» ....Остро, жестко, чтобы было понятно, что вот это запрещено, а вот это разрешено. Не только родители, не только мама и папа, а вся твоя родня тебе об этом говорит» ["Son, don't do any stupid things there. Don't make children before getting married. It is a shame..." They said it strictly for us to understand, what is prohibited and what is permitted. It is not only parents, who tell you this, but all relatives tell you this"] (Interview STT 4.1). All the information about Russia as the place of future studies is actualized through corresponding motivation - the desire to study at a Russian university and organizational and intellectual efforts connected herewith: looking for the options to be enrolled for a budget-funded educational programme, choosing a university: «Ну, в школах приходят, рекламируют. Ну, говорят вот нам,... что есть, ...иансы. Из тех, кто хотят, может поступать, балль набрать, по конкурсу если пройти, можно приехать сюда ...Ну, там у нас приходят каждый год квоты, не только Томск, разные города бывают, там Москва, Питер, и..., вот, ... по крайней мере, Томск был. Я сдал документы, там балль набрал, и вот ошасливился» [Well, they come to schools and promote universities. They tell us that we have chances. Those who can apply and get enough points to get a place at a university can come here... Well, there are quotas each year, not only Tomsk. There are other cities, Moscow, Piterl and..., so to say.., there was Tomsk among them. I submitted the documents, got the points and here I am happy] (Interview STT-6). The level of proficiency in the Russian language was also considered: «У меня дома ещеё родители общаются, все знают русский язык, не только я» [My parents speak Russian at home, everybody speaks Russian, not only me] (Interview STT-6). Another part of the capital is provided by the moral and financial support of the family sending the student to Russia. Obviously, only relatively affluent Tajik families can afford sending their children to study abroad. Finally, the capital includes the position of the Tajik state 
conducting the policy of cooperation with the Russian Federation in the field of education.

Despite the fact that the prospective student acquires this capital in the home country, it contributes to the subsequent changes in their life associated with the movement from their home community to the host community. Therefore, it may be called the "migration capital" of the prospective student. Its typical feature is the incoming role and time constraint. Thus, the migration capital of the prospective student of the Russian university is formed in the period of their life in Tajikistan and getting ready for the trip to study in another country.

\section{Personal and Social Capital Developed by the Migrant Students in the Host Community}

When students come to Russia, they begin to develop their capital inside the host community. Their ideas about Russia start to change - former virtual ideas are replaced by everyday experience: «...я себе как бы вообще.., по-другому представляла Томск ...(смеётся) ну как бы очень большие здания!, ну, как вот Америка там есть. Ну я себе так представляла... И учебные заведения. Я ... вот университет, по телевизору как раз смотрела Москву, там большая, и лестницы такие большие. Я тоже думала, что я буду вот в таком университете учиться. Ну, приехала, тут маленькое как-то. ... ну, не понравилось вначале. Вначале я месяи почти плакала, не хотела (учиться - Н.П.), хотела уйти. Потом уже со временем, когда студенты все приехали, уже знакомые... там, ну, вот, и постепенно уже привыкла ко всему» [Well, I imagined Tomsk a bit different (laughing) with big buildings! Like in America. Well, that's how I thought of it at that time... And educational institutions. I ... The university, I was watching Moscow on TV at that time, I saw a big building, and ladders were so big. I thought that
I would also study at a university like that one. Well, when I arrived, everything was somehow little ... I did not like it at first. At the beginning I had been crying for almost a month, I did not want (to study - N.P.), I wanted to leave. Later, when all the students arrived, already familiar ... well, gradually I have become accustomed to everything] (Interview STT-12). The level of proficiency in the Russian language is evaluated more sensibly: «...я учил вот 11-ть классов русский язык, но ещё уровень русского языка, который в Таджикистане проходят, и уровень русского языка в России - это две разные вещи, я могу сказать» [I had been studying Russian for 11 years, but let me tell you, the level of Russian taught in Tajikistan and the level of Russian in Russia differ significantly] (Interview STT-4). Abilities to adjust to the host community are also evaluated in a new light: $\ll B$ 2010 году нас ...nоступило семеро человек. Из семерых толко двое остались, а остальные не смогли продолжить учебу, у них проблемь c-c-с...речью. И..., с знанием. Не хватало» [In 2010 there were seven of us who entered... Only two out of seven stayed, and others were not able to continue their studies, they had problems with speaking. And..., knowledge. It was insufficient] (Interview STT-2). The same situation was commented by another Tajik student from the same Tomsk university: «Ну, эти парни, они вообще не знали русского, один вообще не знал русского. Ну, как-то поступил? Как-то! (усмехается)... Явот такихлюдейнепонимал, и не понимаю до сих пор. Ну зачем ехать в чужую страну, которой не знаешь языка? И на что-то, на чудо какое-то надеяться.» [Well, these guys didn't know Russian at all, one of them didn't know a word in Russian. Well, he entered the university somehow, didn't he? Somehow! (grinning) ... I have never understood such people. What for to go to another country if you don't speak the language of the country? 
And then wait for some miracle] (Interview STT13). The realias of Tajikistan are now evaluated through the prism of everyday life in Russia: «Tут, например, надо все..., на всех семинарах там учиться, отвечать, ну, как я вот, по своей практике. А там вот, ну, можно ... деньги заплатить» [Here, for example, you have to... study at the seminars, answer the questions about your internship, like me. And there you can, well, ... pay money for it] (Interview STT-4). Sometimes those stereotypes that were formed during preparation for the trip to Russia based on the materials of TV shows demonstrating violent attitude towards Tajik migrant workers or on TV series "Our Russia" become blurred: «...у себя сльшал, что ребята ездят в Россию зарабатывать... и там же всякие скинхеды, ...что убивают кого-то, кого-то там побили, плохое отношение вообще, $и$ «Наму Рашу» посмотрел, думал, что будет всё очень плохо. Но тут оказалось, что отночение вообще очень нормальное, с ребятами познакомился, всё очень хорошо. ... я боксом занимаюсь..., думаю, щас с русским встану ... он меня так будет долбить. Оказалось, что он ... опытнее меня, ...он как бы со мной легче работает, зная, что новичок. ... и удивило то, что, почему у нас такое отнотение, такое сложилось в голове, что там будет всё так, что враждовать будем между собой? ... вот я приехал, и понял, что, ну, может там в Москве и где-то ещё там есть такое, то именно в Томске всё очень хорошо, мне прямо очень здесь нравится». [At home I heard that guys go to Russia to earn money... and there are those skinheads,... that they kill somebody, or hit somebody, I thought the attitude is bad, and when I saw "Our Russia" I thought that everything would be really bad. But it turned out that local people treat us nice, I've got to know other students, everything is very good... I do boxing..., I think if I meet the Russian at the squared ting, he will hit me badly. But it turned out that even though he was ... more experienced than me, ...he worked easier with me because he knew I was less experienced. ...I was surprised why we have this perception in our heads, that everything would be so, that we would fight each other?... Here I am, and I understand that maybe in Moscow and somewhere else there it can be so, but in Tomsk everything is very good, I really like it here] (Interview STT-9).

It can be assumed that the structure of this new vision of socio-cultural realias of Tajikistan is highly controversial. The patterns related to the attitude to parents, marriage, for example, remain basically the same: «У меня, как бы, хоть и родители образованные люди... они мне сказали, когда я на первом курсе... «ты знаешь, что у тебя жена будет таджичка». [My parents are, so to say, educated people... but they told me, when I was in my first year... "you know, your wife would be Tajik"] (Interview STT-13). But evaluating the quality of life and prospects of professional career after the university, they prefer to stay in Russia: «Hy бы хотел... здесь работу хорошую найти, взять жену-таджичку, и переехать» [Well, I would like... to find a good job here, to marry a Tajik girl and to move] (Interview STT-13). «Как родина - я люблю Таджикистан, но как место реализации чего-то, это негодная страна» [I love Tajikistan as my home country, but as a place to do something it is a bad country] (Interview STT-4.1).

As many students in general, students from Tajikistan find part-time jobs. They unintentionally compare their earnings with the situation in Tajikistan: «Мне предлагали убирать помещение, ... они платят семь с половиной тиссяч.... Я два-три часа каждый день работаю. Это вообще хорошие деньги» [I was offered to clean the room, ... they pay seven thousands and a half ... I work two-three 


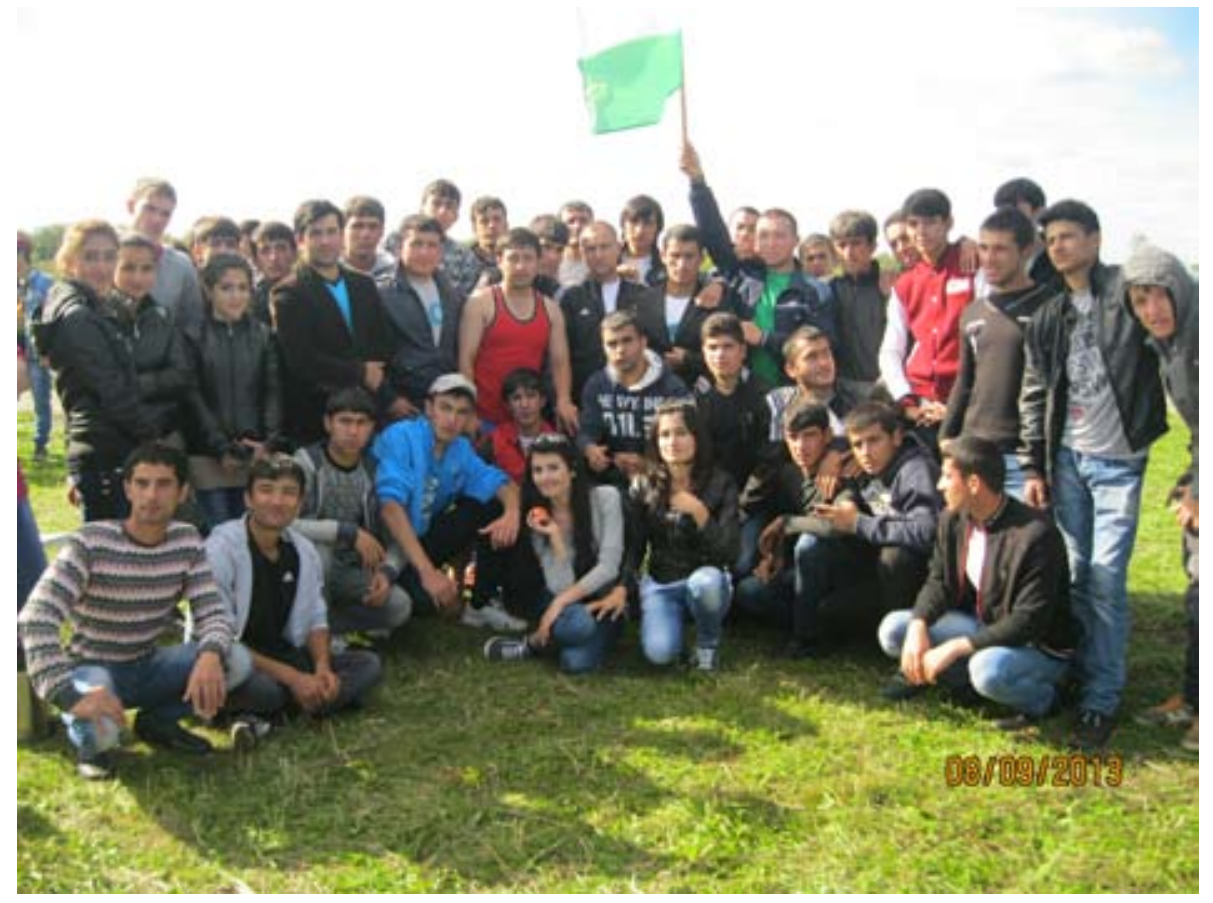

Fig. 7. Young people from Tajikistan (students and workers) on a picnic in Tomsk on the Day of Independence of the Republic of Tajikistan on September 9

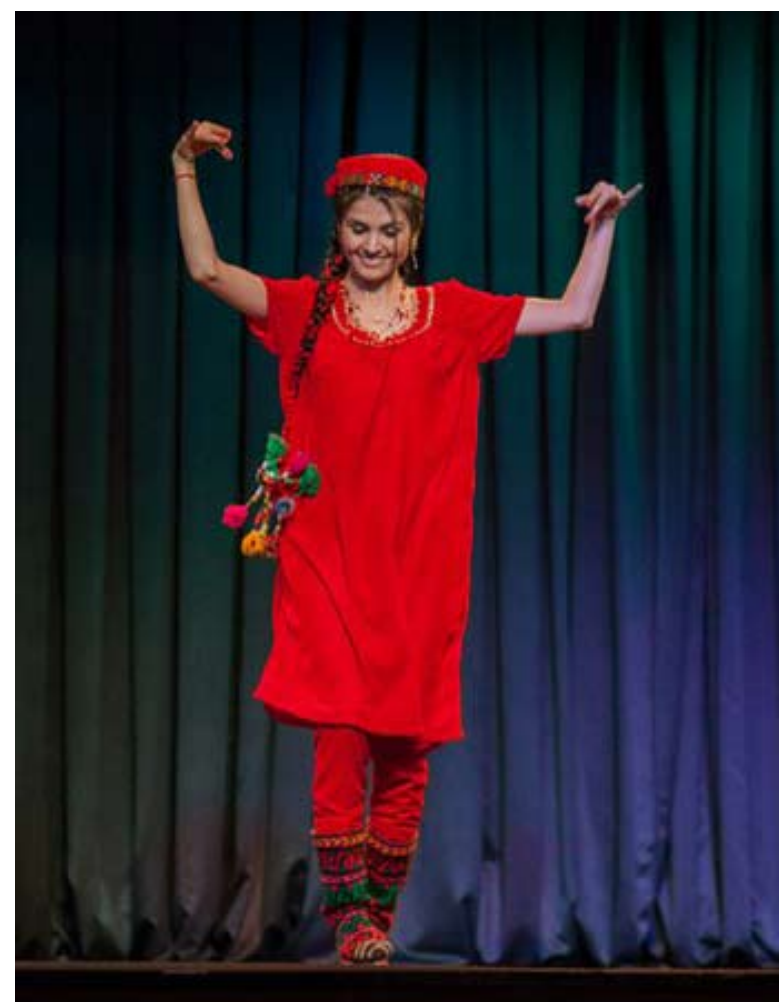

Fig. 8. Pamirs dance in Tomsk State Architecture and Construction University, where the students from GornoBadakhshan - the most southern part of Tajikistan - study 


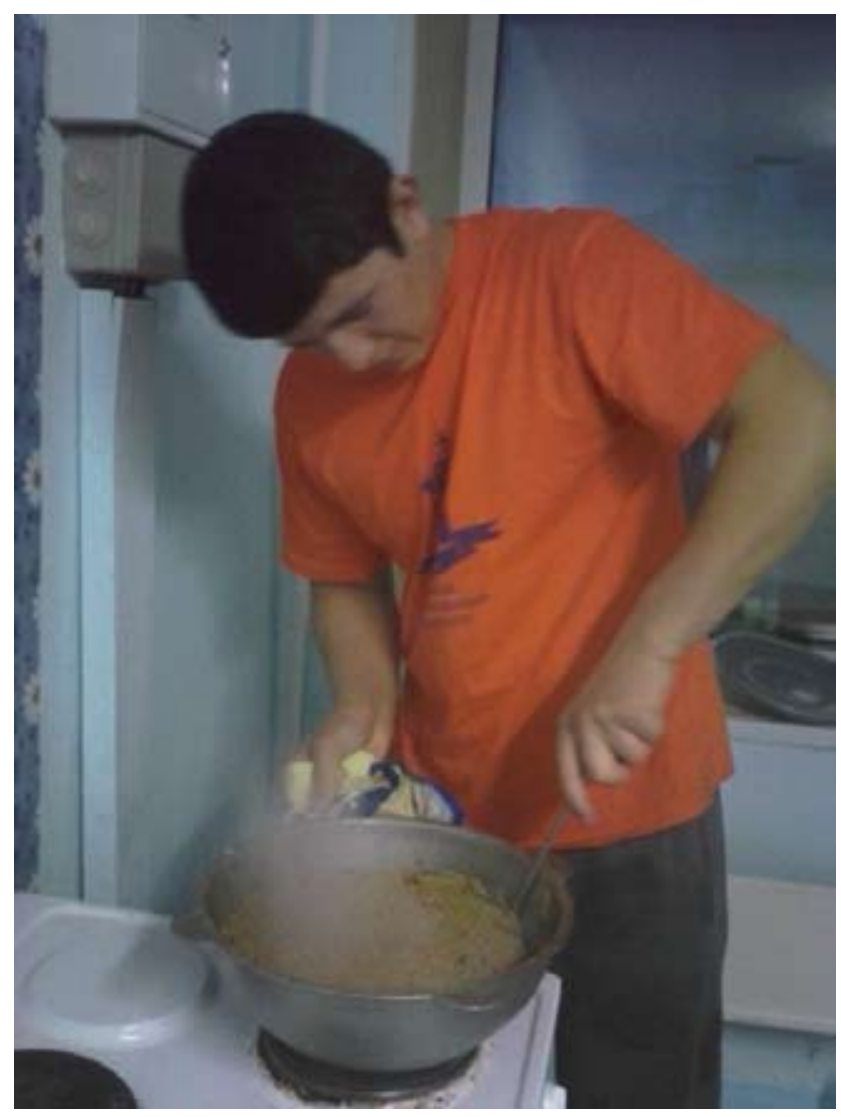

Fig. 9. Cooking the Tajik pilaf in the deg (a special cauldron) in the dormitory's common kitchen

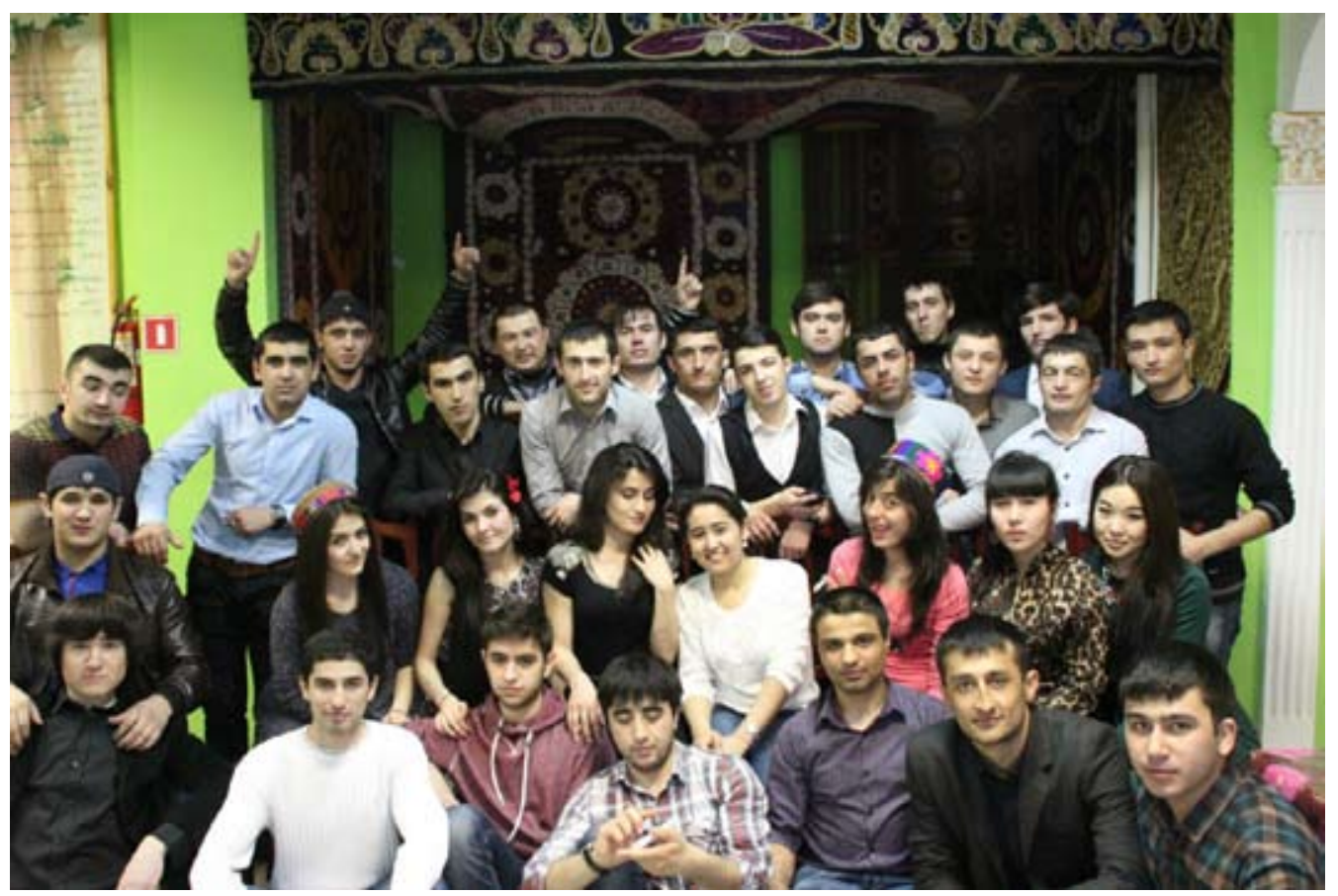

Fig. 10. Students and workers from Tajikistan celebrating Nowruz in Tomsk 
hours every day. The payment is really good] (Interview STT-10). According to the data of the BusinessForecast.by research group, the average salary in Tajikistan in 2013 (after income tax profit and taking into account the purchasing power balance) was 283.7 \$ (Reiting...). That is about 8,800 rubles (the exchange rate for dollar in 2013 was about 30-32 rubles).

In the situation of gradual adaptation, the patterns can conflict at the inter-personal level: «Один раз, просто когда ехал в автобусе... вот у нас воспитание, что взрослье заходят, надо вставать, уступать место... А здесь, такого нет (смеётся) ... один раз девушка просто зашла в автобус, я встал, «садитесь, девушка». Ну, она на меня наехала с такими словами, что, «я что, такая старая, чтобы ты мне уступаешь...». Я просто промолчал, сел обратно, и я как-то уже опасаюсь комуmo ycmynamb» [Once, when I was in the bus... we are taught that when adults come in, you have to stand up and give up the seat. And here it is not like that (laughing)... once a young woman came into the bus, I stood up and invited her to take my seat. Well, she had a go on me with the words, "what do you think, that I am so old, that you give up your seat to me...". I didn't reply and sat down, now I am afraid to give up my seat to anybody] (Interview STT-13)

Most likely, the process of refocusing on the social realias of the host community is not straightforward. It may be influences by the influence of parents, who advise to maintain active ties with their homeland, to come back home after graduation, and frustration associated with failure in studies or other adaptation problems. But on the whole, the structure of the fields of the migrant student living space is changing in favour of a deeper immersion in the realias of the host community and certain distancing from the realias of the home country: « ... со мной..., вот парень живёт,... он уже ... магистратуру заканчивает... Он говорит, я останусь тут, потому что я не могу больше в Таджикистане жить. ... когдая яедудомой, тамужекакбудто я не у себя дома там. У всех другие мысли, ... всё по - другому делается, мне это, ну, не подходит больше. ...Ну, буду ехать туда,... не буду навсегда тут оста..., но жить-то тут буду. Потому что уже привычно тут жить, так, как живёшь». [... my roommate...he has almost finished his Master studies... He says he will stay here, because he can't live in Tajikistan anymore... When he goes home, it is like it is not home anymore. People have different thought, ... everything is done in a different way, I don't fit in there anymore. ...I will go there,... I won't stay there forever, ...I will live here. Because I've got used to life here, to the way I live] (Interview STT-4)

The capital of a migrant student formed in the host society is characterized by cultural binarity refracted through the prism of personal characteristics of a particular individual. This binary cultural capital is operationalized in a particular quality of bilingualism, partial assignment of the host community patterns that are superimposed on the patterns of the Tajik culture. Herewith, firstly, there is a process of situational adaptation and, secondly, a more prolonged process of enculturation of the student from Tajikistan in the host community.

In the future, the dynamics of the binary culture will depend on certain social courses of a university graduate in Russia. In terms of the disperse residence of the diaspora, its representative will increase the components of Russian culture in their binary capital. The limits of this process will be determined by their personal abilities to enculturation and the needs of their professional and social course. In the case of residence in the national enclave, enculturation will be determined by the needs of interaction with the host community. If their social capital 
is formed mainly in professional, public areas of the host community, then the process of enculturation will continue. If the social capital accumulates mostly in a family environment or fellow countrymen environment, the process of enculturation will either slow down or stagnate at a relatively low level. In the family started by a young native of Tajikistan with Russian university education, their binary culture will affect their children born or at least brought up in Russia.

The process of enculturation of foreign students may be also considered through the statement of Bourdieu that "the ability to dominate in the appropriated space, mainly due to the appropriation (material or symbolic) of deficit resources that are distributed in it, depends on the available capital" (Bourdieu P . 1993, p. 43). Young people from Tajikistan gradually accumulate this capital during their student years through various kinds of social activities: educational, recreational, household religious and working.

For many Tajik students studying at the university, especially during their first year, it is quite difficult. Difficulties occur, for example, with taking notes of lectures. Due to the lack of proficiency in Russian, some students translate what they hear into the Tajik language and take notes in their native language. Universities offer courses of Russian as a foreign language, but they are not included in the compulsory curriculum. Notwithstanding their poor knowledge of the Russian language, students often think it is not necessary to take such courses. One of the graduate students of one of technical universities of Tomsk responded to the question whether he had taken any additional classes of the Russian language, as follows: «Не, не ходили, там, просто у нас тестирвание прошло, кто нормально тестирвание проходил, им, сказали, не надо. Мы написали очень..., на среднее написали, и нам сказали, не надо. И ми, каждый раз там вот на всяких лабораторных, конференциях участвовали и активно в университете образ жизни проводили, и из-за этого свободно разговариваем» $[$ No, we didn't take. We had a test and who did ok, they told us we didn't have to come. Our results were..., average and they told us we didn't have to come. And we always took part in various laboratory works, conferences and actively participated in the university life, that's why now we speak fluently] (Interview STT-2)

Sometimes, those who want to improve their level of Russian, cannot find an appropriate course: «...Ну, как я приехала, я говорила, что я затрудняюсь по поводу языковой и я понимаю очень хоромо, но я не могу выражать своего мысля, как я хочу, как я понимаю, потому что мне хватает этого. Ну, мне посоветовали, что есть такой курс русского языка в нашем университете, мне познакомили с преподавателем. Э-э-э... этот преподаватель со мной пообщалась. А,...она говорила, что, «моя группа состоит из китайщев»... очень более, такой, как называется... «на уровне моего студента, Вы на один ступенька выше»; поэтому Вы зря своего время тратите с моими студентами ходите, потому что они изучают слова еще, a Вы очень много слов знаете, но просто Вы на втором ступеньке, а до этого еще мы не прошли. Так что уменя группа, к которойменя поставили не соответствовала, поэтому, ... я сама начинала самостоятельно учить» [When I came here, I said that it is difficult for me to speak, but my listening skills are very good, but I can't express my thought as I want, as I understand I lack these skills. They gave me advice that there was a course of the Russian language in our university, I got acquainted with the teacher. Well, ... this teacher talked to me. Ah,... she said, "my group includes only Chinese"... it is more, how to say... "at the level of my student 
you are one step forward"; "you waste your time studying in the group with my students, because they are just learning words and you already know a lot of words, you are at the second level, and we haven't got to this level yet". So I didn't fit in that group I came to, and... I began to study on my own] (Interview STT-5). Difficulties appear in the course of preparation for seminars, when it is necessary to read the materials, understand them and then answer in the class. Sometimes, as the respondents note, one can rely on the help from other students, but not always: «... что будет непонятно, обрамаюсь культурно, они объясняют всё. Если не хотят, то говорят: «не смогу», или «забыла», «ой, я сама не знаю, спроси другого». Это нормально, я думаю». [... if I can't understand something, I ask them nicely and they explain it to me. If they don't want to, they say, "I can't" or "I forgot", "I don't know, ask somebody else". I think it's ok] (Interview STT-5). Sometimes students from Tajikistan feel that others consider them to be outsiders in the group and do not want to help: «...Начинается пара и говорят - разделитесь по группам, чтобы сделать задание. Получается так, что mы попадаешь в группу и те, кто с тобой в группе, ну, мимикой, не знаю, тоном разговора тебе дают ясно понять, что мы, вот, будем работать, а ты ничего не сделаешь, потому что, ну, как бы ты не шаришь, не знаешь ... бывали такие моменты, что вот приходилось ... говорить, что ну зачем - если не хотите, то я буду, нукак бы даже один работать, но не надо вести себя так». [... The class begins and the teacher says to divide into groups to do the task. And it happens so that you get into a group and other members of the group, well, miming, I don't know, by the way they speak to you make you understand, "we will work together and you will do nothing, because you don't know a thing"... there were such moments when I had to say that if they didn't want me in a group, I would work alone, and asked them not to behave that way] (Interview STT-4.1). It is difficult to take tests, examinations and defend term papers. This is due to the poor command of the language, and gaps in seminars and lectures during the semester, and lower knowledge of some school subjects in comparison with Russian students. In Tajikistan, even in the Russian classes the curriculum does not include the history of Russia. According to the students, they are not familiar with the concepts of philosophy and psychology. In field practical training, migrant students feel much more confident due to their communication skills, endurance, diligence and willingness to help. The same applies to various departmental activities and student conferences. Tajik students rarely make reports, but actively participate in organizing and performing these activities. For internships, they try to apply for the companies or institutions where Tajiks work.

Leisure time of the students is a very important channel for their adaptation and enculturation. The forms of spending free time are quite varied, although most of the time located within the university campus, cafes located in the university part of Tomsk, and the places where the representatives of the diaspora gather together. Much attention is paid to sports. Respondents mentioned mainly team sports such as football, basketball, volleyball, and strength sports: ultimate fighting, boxing, kickboxing, powerlifting and weightlifting. Tajik students are in the teams of departments in various sports.

There are not too many female students from Tajikistan at Tomsk universities, therefore young men often get acquainted with and date Russians. It contributes to the knowledge of the intricacies of the host community culture and improvement of the language proficiency. Usually male students from Tajikistan are rather restrained, do not consume any alcohol and do not use any swear words that could make a good 
impression on the girls. But according to many students, romantic relationships have definite limits due to national traditions and religion. Young people usually associate their matrimonial plans with Tajikistan: «... $я$ собираюсь этим летом ехать, посмотреть на девушек, которые мне выбрали. Ну, посмотрим...Я точно не знаю, какая будет жена у меня, ну, вроде на примете есть одна, там выбрали, сказали. Ну, это моя дальняя родственница, очень дальняя, она учится в медицинском университете, в Душамбе. ...Я сначала женюсь, потом там буду в Таджикистане несколько месячев, потом приеду сюда, чтоб получить гражданство тут». [... I plan to gо there this summer, to look at the girls that have been chosen for me. Well, we'll see... I don't know what kind of a wife I will have, but there is one there, they told me they had chosen. Well, she is my distant relative, very distant, she studies at medical university in Dushanbe. ...First I will get married, then I will stay in Tajikistan for several months and then will come back here to get a citizenship here] (Interview STT-7)

Students from Tajikistan spend a lot of their leisure time participating in festivities. In Tajikistan, which ranks last among the CIS countries by the gross domestic product, the massive city festivals are held only in the capital and major cities. Therefore, the City Day in Tomsk attracts the attention of the Tajik students. They also participate in various university celebrations, in which representatives of different nationalities take part. But most attention is paid to the participation in Nowruz in Tomsk - celebration of New Year according to the astronomical solar calendar, which is celebrated by the Iranian and Turkic peoples. The holiday is a good opportunity to maintain the national reflection through meetings, a joint meal in a national cafe owned by Tajiks, national songs and dances. Judging by available photographs and comments to them, students spend the holiday together with representatives of the Tajik diaspora and migrant workers. They also celebrate the main Muslim holidays - Eid al-Fitr and Eid al-Adha. However, as students say, due to severe climatic conditions for them, before the feast of Eid al-Fitr not all them fast during the holy month of Ramadan. Even though sometimes they do not go to the mosque on Fridays, on holidays students usually go to the mosque early in the morning. On Eid al-Adha, local co-religionists treat them meat there. Out of the two Tomsk mosques - the Red and the White - Tomsk Tajiks prefer the Red one, where the imam is a Tajik Nizamuddin Zhumaev (Krasnaia mechet' ...). Though this mosque, as well as the White mosque, is not attended by students from Gorno-Badakhshan who are Shia Ismaili. Most of them study at Tomsk State University of Architecture and Construction (TGASU). Having an opportunity to participate in religious holidays in Tomsk, the students, however, note that in Tomsk the spirit of these events is different from Tajikistan: «O, это очень как бы...(ульбается) Во-первых, атмосфера - тут ошущается, что, вот, праздник, ну, когда ты приезжаешь в тот же мечеть или, не знаю, к каким-то землякам, что вот Навруз или Курбанбайрам, что вот праздник, ну как бы стол накрыт, ну, достархан накрыт - есть всё. Но той атмосферы, которая в Таджикистане, что каждый дом этот праздник празднует, каждый, там... дети ходят, шумят, веселятся, что ты можешь к любому зайти и там помолиться, там, не знаю, поесть, встать и уйти, как бы такого тут нету. Всё равно атмосфера другая. Даже не, даже тут, в России, там, не знаю, в Чечне или, не знаю, в Дагестане или в Татарстане - такая же атмосфера. В Томске этого нету» [Oh, it's like ... (smiling) First of all, the atmosphere - here you feel that there is a holiday, well, when you come to a mosque, or, I don't know, to some countrymen, 
that it's Nowruz or Eid al-Adha, it's a holiday, the table is laid, well, the dastarkhan-everything is on the table. But the atmosphere is different from Tajikistan, when there is a celebration in every house, everyone celebrates there ... the kids go, make noise, have fun, you can come in any house and pray there, I don't know, eat there, stand up and leave, there is nothing like that here. All the same, the atmosphere is different. Even here, in Russia, I don't know, may be in Chechnya or in Dagestan and Tatarstan, the atmosphere is like that. In Tomsk it is not] (Interview STT-4.1). These words demonstrate that cultural distance, that difference in the celebration of the holiday at home and far from it, in Russian regions with predominance of Muslims in Tomsk.

Some meetings of students organized by the Tajik diaspora together with the leaders of public organizations in Tomsk, are devoted to the famous representatives of Tajik culture of the past eras. One of the literary evenings, for example, which was held in the Russian-German house, was dedicated to the poet, philosopher and scientist Omar Khayyam.

Within the leisure sphere, conflicts occur involving migrant students. That is, as the American sociologist L. Coser wrote, a completely natural part of social interaction (Coser L.A. 2000) .Conflicts arise, at times, between the Tajik students from Badakhshan on the one side, and the Tajik students from other regions of Tajikistan on the other. Usually the clashes occur between the groups of youth in the sphere of culture and sport. During the Nowruz celebration in 2013 a clash between students from Gorno-Badakhshan and Kulob occurred because of the music in the cafe, where they celebrated the feast: «Изначально все были вместе, ... и стариие и руководители и учредители, все были вместе. Но так как они уехали и это как в школе, когда последний звонок, когда директор и физрук уехал и всё начинается.
Там такая же ситуачия. Кто-то хотел сказать... ну, может они подразумевали, что вот мы круче вас, вы должны делать, как мы говорим. Может вообще просто хотели слушать свою музыку - я не могу это сказать как они хотели, но конфликт был, конфликт был очень серьезный и слава богу, что они решили всё это мирным путем» [Initially, everyone was there together ... and the elderly, and the leaders and founders, all were together. But as they left, and it's like at school after the last call, when the director and the PE teacher leave and then it all starts. There was the same situation. Someone wanted to say ... well, maybe they meant "we are cooler than you, you must do as we say". Maybe they simply wanted to listen to their music, I can't say what they wanted, but the conflict was, the conflict was very serious, thank God, that they resolved all of this in a peaceful way] (Interview STT-4.1). Sometimes confrontations happen during sport activities. Like the one between the students from Gorno-Badakhshan and the students from Dushanbe: «... был тренировочный день ... Сняли, вот, спортивный комплекс, пришли тренироваться. Все были таджики - ребята из Памира, ребята из Душанбе, ребята из Куляба - со всех регионов Таджикистана. Собрались командой. Ребята из Памира $-y$ них своя команда. Ну и они начинают грубо играть. Им объясняешь, что так играть не надо, они начинают, как бы вот... как хочу, так играю. ..... Дочло до того, что чуть до драки не дошло. Ну, а, не знаю, в своей физической подготовке я всегда был уверен и если б до драки дошло - никто не смог бы остановить, но, слава богу, опять же всё решилось тем, что поорали друг на друга и успокоились» [... it was a training day ... We rented a sports complex and came to work out. All of us were Tajiks - the guys from the Pamirs, the guys from Dushanbe, the guys from Kulob- 
from all regions of Tajikistan. We gathered as a team. The guys from the Pamirs - they have their own team. So, they start playing rough. We explain that it is not necessary to play in such a way, they start, ... I play as I want to. ... There was almost a fight there. Well, I don't know, I have been always confident of my physical shape, and if it came to fighting - no one would stop me, but, thank God, again everything was resolved down] (Interview STT-4.1). Apparently, there is an implicit influence of the cultural, linguistic and historical distance that exists between Sunnis and Shia Ismaili, those sharp political contradictions that exist in the modern Tajik society. According to the respondent, during the conflict in the cafe caused by trivial disagreement about music, the students from Gorno-Badakhshan said: «Mын не таджики, мы хотим жить отдельно, мы хотим отдельное государство» [We are not Tajiks, we want to be independent, we want an independent state] (Interview STT-4.1)

Most students from Tajikistan live in dormitories. This is definitely one of the main loci of adaptation of migrant students to the new reality. But it is there, during the first days and months of their life in Tomsk, where students from Tajikistan often experience the culture shock, which suggests serious differences in the everyday practices of the inhabitants of the two countries: «Когда я приехала, мне неприятно было ...в душе одном мыться... Может быть, это зависит от моего воспитания, что мы болееменее скромные, нам воспитали так, что женщина всегда должна быть свои прелести не показать... А когда я в душе, все мы вместе зашли, чуть-чуть для меня это неприятно било» [When I arrived, I did not like it ... that we shared the shower ... Maybe it depends on my upbringing, that we are more or less modest, we have been brought up in such a way that a woman should never show her lady parts ... And when I was in the shower and we were there all together, it was a little bit uncomfortable for me] (Interview STT-5). « ...я был очень шокирован ... когда ты встаёшь в первый день утром, выходишь в секцию в общежитии ... умыться и видишь там девушка ...в иортах, которые, не знаю, короче твоих трусов... это вообще иок - что делать?! Ну, приходилось обратно заходить в комнату пока как бы все не уедут или не умоются» [... I was very shocked ... when you get up in the morning the first day, you come out in the section of the dormitory ... to wash your face and there you see a girl in shorts ... which are, I don't know, shorter than your panties ... it was really shocking - what shall I do?! Well, I had to go back into the room and wait until everybody else leaves or washes up] (Interview STT-4.1). However, both respondents noted that they have become accustomed to the manners of Tomsk dormitories quite quickly. But there is something that seems to touch deeper layers of morals and even with time there is quite a definite rejection: «Здесь непривычно что, вот...много они себе позволяют... курят, бухают... У нас в Таджикистане какбы не до такого степени..., ну там таким вещзам редко занимаются. A вот здесь... например, там новогодние праздники, день радио..., они просто вот, с утра, с ночи они бухают. Чё за традиџия? Я вот не знаю...» [It is unusual that, ... they allow a lot to themselves... they smoke and drink ... In Tajikistan we don't have it to such an extent .... well, people are rarely involved in such things there. And here ... for example, there are the New Year holidays, the day of the radio ... they just begin to drink from the morning, from the night. What kind of a tradition is that? I don't know ...] (Interview STT-2) Conflicts occur in relation to different understanding of religious rites: «... студент приехал - он... встает в пять утра молиться, а в это время... другие спят. Вот и как бы получается так, что другие начинают спрачивать... почему ты это делаешь, тьл 
как бы учитывай, что мы тоже тут живем. Вот, ну а этому студенту, понятно, что с самого детства воспитьввали, что вот в это время ты обязан вставать, ... делать этот обряд, молиться и всё. И поэтому бывало что конфликты из-за этого. Но всё это со временем уходит, многие стараются потише быть и, не знаю, совершать молитву в то время, когда соседей нет или многие просто не молятся. Ну, вот это как бы уже идет адаптация к новой культуре $u$ поведение менять надо бы». [... a student arrived - he gets up ... at five in the morning to pray, but at this time ... others are sleeping. So it turns out that others begin to ask ... "why do you do it, take into account that we live here, too". So, this student has been taught since his childhood that at this time he has to get up ... to do this ritual, to pray and so on. So there were conflicts because of this. But it all goes away with time, many try to be more quiet, and I don't know, to pray when the neighbours are away or many simply do not pray. Well, it is already an adaption to a new culture and behaviour should be changed]. (Interview STT-4.1)

In the dormitory it is very important who would be a roommate. Usually, rooms are intended for three or four people. There are some departments, where many immigrants from Tajikistan study, then they can be settled together. If there is one or two students, they will be inevitably settled with the Russians. The students themselves are rather ambivalent in such cases. They like to live with their countrymen, but, at the same time, they realize that it will negatively affect the quality of their conversational language and their adaptation to the culture of the host community. (Pogodaev N.P. Vladenie ... 2015). There are no such university policies that would be aimed at dispersed settlement of students with the view of deeper adaptation and enculturation. Differences in upbringing of Russian and Tajik girls also sometimes causes conflicts in the room. At one of the departments, a Tajik student was outraged by the fact that her Russian roommate invited her boyfriend to their room. At first, she was embarrassed, and then the situation escalated into a conflict. At home, the Tajik girl has been taught since childhood that there should be no meetings between young men and women before the wedding. There were conflicts on other issues as well: «в маленьком комнате мы три девушки жили, у нас был, что мы друг друга не понимали. Мне, как я приехала, мне в письмо написано было, что обеспечивать общежитием, мне дали комнату как студентка иностранный такой, более-менее условия хороший. А девушка, которая жила раньше, она приехала чуть-чуть позже, она недовольство..., говорила, что я нехочужить с этой девушкой... Конечно, это неприятно было, когда меня обзывала: "Дура! Я с таким дуром не хочу жить». Я говорила: "Я эту комнату не выбрала, и тебя не выбрала, меня так выселили (заселили-Н.П.), чёя виновата, что ли, что ты не хочешь со мной жить?» Потому что она девуика более-менее совре... свободная была. Мне было неприятно, но я потом, ...у-y-y , как назвать... потом поняла, что это нормально (философским тоном). Ну, человек не хотела, а чё? Плюс к другому потом меня выселили, очень хорошо и дружно мы жили, общались» (с другими соседками в другой комнате - Н.П.) [there were three of us in a small room, and sometimes we didn't understand each other. When I came here, I had the letter where it was written that I would have a room in the dormitory. I was settled in a very good room as an international student. And the girl who had lived in the room before, arrived later, and she was ... not happy with it, saying "I don't want to live with this girl" ... Of course, it was frustrating when she called names, "Stupid! I don't want to live with this stupid girl'. I said, 
"I haven't chosen this room, and haven't chosen you (as a roommate - N.P.). Is it my fault that you don't want to live with me in one room?". Because she was a girl more or less ... she was free. It was frustrating, but then I ... how to say it ... then I realized that it is normal (in a philosophical tone). Well, she didn't want to, so what? And then I was settled to another room and we lived together very well, communicated (with roommates in another room - N.P.)]. (Interview STT-5)

Like many Russian students, young people from Tajikistan during the years of study work part-time as security guards in clubs, pubs, restaurants and companies, loaders in big stores, rouse-about at construction sites and works related to territory improvement. Most often, it is "semilegal employment" without a formal employment contract. Official employment is only possible in summer student construction teams. Female students from Tajikistan try to find work in the companies of their countrymen: «... они, всётаки наша культура, знает этот человек, как к девушке восточной относиться. Как бы нормально, хорошо работать». [...they are, after all, our culture, they know how to treat the girl form the East appropriately. How to work normally, well...] (Interview STT-10)

\section{Social Courses of the Future: Steps Up and Down.}

After arriving from Tajikistan, graduating from Russian universities and staying in Russia to continue their future life here, Tajik youth becomes a part of the Russian society. Their personal and social capital accumulated at home country and in Russia allows to build a configuration of social ties. According to Bourdieu's opinion, “the capital allows one to keep at a distance from unwelcome people and objects and at the same time to get closer to the preferable people and objects, thus minimizing the expenditures (especially time ones) required to appropriate them (Bourdieu, P., 1993, p. 43).

The symbolic capital of double enculturation allows young people from Tajikistan who have graduated from Russian universities, to be present in the symbolic space of certain social fields of both countries. This symbolic presence also becomes the basis for the physical appropriation of the loci of Russia and Tajikistan through physical and social mobility providing an access to the "spatial profits" (Bourdieu, P. 1993, p. 44).

The level of university graduates enculturation in the local community can be assessed through their further social activity in a predominantly homogeneous groups of immigrants from Tajikistan or in groups mostly consisting of representatives of the host community. First of all, it concerns professional work, where professional competences, language and cultural patterns are crucial. Those who were unable to obtain the capital required for the access to relatively deficit social resources of the host community, will have to settle for less deficit, less efficient resources, which restrain the development of the personal and professional course. The marginalization of an individual, who has partially lost the capital of their native culture, who has distanced from it and has not managed to form the appropriate capital in the space of the host community during the study at the university, becomes a serious obstacle to further material and symbolic appropriation of social spaces of both home and host communities, for the formation of the personal and professional course.

Ghettoization of migrants from Central Asia in modern Russia is sometimes considered literally as creation of physical loci for migrants unable to live in other, more prestigious conditions. But such physical localization of migrants in some Russian cities, first of all, is weak due to social syncreticity of the city space, and, secondly, it is 
only a physical projection of a wider phenomenon of symbolic ghettoization. Students from Tajikistan in Tomsk and other university cities of Russia do not have any relation to certain forms of physical ghettoization. Their everyday practices are connected with student life, they live in student dormitories. Therefore, at this stage of life students from Tajikistan are quite well incorporated in the adequate social space of the host community. But some of them already during the years of study or after graduation may experience certain features of symbolic ghettoization. Here we can apply Bourdieu's thesis about the "club effect" and the ghetto effect as the methodological basis for understanding of this situation (Bourdieu, P. 1993, pp. 4849). The "club effect" refers to those who after graduating can find a job in their degree field, apply their professional competencies and enter the corresponding higher layers of the society. Integration into these society layers allows to further develop social ties among those who have an access to the deficit resources: occupation connected with intellectual and not physical labour with the prospects of salary increase and career progress in production and social structures, an access to the work in municipal and government management structures, to political activities and to higher status positions in the matrimonial field.

During the years of study, the students form certain social relations. At this stage, this process is not well reflected. Only after some time a friend you studied with, went with to the parties, worked together with in the construction team or who was your roommate in the dormitory, becomes an important figure in the economic, political or social field. If childhood friends of students from Tajikistan, their different family and clan resources are located in another subspace, friends from the period of studies are formed mostly in the student's community - the main symbolic and physical locus of the host community sub-space. Later, they can become one of the privileged resources of young Tajiks, who have graduated from Russian universities. Culture binarity plays an important role herewith. Some graduates may count on further development of the ties among ethnophor peers and members of the Tajik diaspora well settled in Tomsk. We can assume that a typical feature of socialization of a graduate in this field will be "a solid basement, but a low ceiling", i.e. reliable moral support from countrymen, but worse prospects of growth in the field of deficit social resources. Socialization in the field of the host community can be determined as "a weak basement, but a high ceiling". Friendship ties from the student years can significantly help in further professional and social promotion. But here "tiny aspects of cultural and linguistic capital, such as manners and accent, etc. play an important role" (Bourdieu, P. 1993, p.50).

The social capital acquired during the years of study at the university produces the "club effect" on the successful students from Tajikistan providing them with an access to the social lifts in the fields of both home and host communities. In Russia, a certain social support may be provided by successful classmates out of native citizens and generation social networks formed on their basis. Inter-generation transmission of the family capital typical for native citizens can to a certain extent serve in favour of those, who are the "members of the club". Thus, when the natives of Tajikistan are looking for job opportunities, family ties of their university friends out of local residents can play a significant role.

Students from Tajikistan, who have not managed the necessary level of adaptation and enculturation during their years of study, can be frustrated due to unfulfilled expectations from studying in Russia: «Я-то думал, что они подскажут, как мне, или нам, группе, как войти в ...международную среду бизнеса, 
как... показать входы и выходын.... каксоздать свою компанию, там, например. И как войти в рынок, быть конкурентноспособными. Ну, мне этого не хватает реально... А про реальное вхождение, там, например, так-то нам ничё не говорят. ...» [I thought they would tell me, there, in the group, how to enter... the international business field... show me the ways... how to establish my own company, for example. How to come to the market and be competitive. I really lack this knowledge... Because theydon't tell us anything about real market things] (Interview STT-7). They would not have an access to the resources of further socialization that they could have counted for after getting a diploma from Russian universities. They would not be able to get a prestigious intellectual job providing a good level of life, they would not have an opportunity for professional development and social recognition. One representative of the Tajik diaspora of one of the major industrial Siberian cities said that job placement for university graduates is a very big and painful problem: «...здесь, вот, в нашем крае вот такая проблема, что иностранные студенты, которые заканчивают, сложно ... в дальнейшем работать здесь. Потому что не берут таких, не каждого берут, и не каждый может по профессии работать... Это очень большая головной бол для нас тоже, для молодёжь, потому что мы сколько лет учились здесь, заканчивали, да, мы не можем здесь по диплому работать уже» [here in our region, there is a problem that international students who graduate ... find it difficult to work here. Because such students are not selected, not everybody is selected and not everybody can work in compliance with the degree... It is also a source of major concern, for us, for young people, because we have studied here for so many years, graduated and now we cannot find a job according to our specialization]. Regarding the reasons of the situation that has occurred the respondent said: «Вот это проблема власти» [It is the problem of the government] and added: «видят - не русский... Такая проблема существует и здесь существует» [When they see that they are not Russian... There is such a problem here] (Interview TDKr-1). It is noticeable that the respondent claims the government to be the main actor of the job placement process, and not the business. Such position may be caused by paternalistic settings typical for the people of Tajikistan. Or may be the image of "the other" for them exists in the syncretical form. The Russians perceive life in Russia through the integral image of the state, the society and private companies. Though people with higher education are expected to have a different reflection. Regarding the ethnic feature as the reason for refusing in job placement, in real situations it is not the ethnic feature that caused the refusal, but the lack of the Russian language proficiency and professional competences. Siberia has never been monoethnic and according to businessmen they care more for the competences of the specialist, rather than their ethnicity. Therefore, such evaluation of the problems with the job placement is based on the distortion of the cause-and-effect linkage. Many university graduates see the way out in returning to Tajikistan, where the Russian diploma is highly valued in terms of employment, said the respondent. But he also noted that the received education is not supported by practical skills and professional competences: «..y ребят нету практики. Учеба одно, а практика-другое. Во времяучебы прохождение практикионизаэто короткое время они не могут.. я считаю так, что ребята не готовы». [... guys don't have any practical experience. Studying is one thing, and practical training is another. During their studies they have little time for practical training, I think that they are not ready] (Interview TDKr-1). One of the main barriers on the way to getting quality education and successful building of further social 
courses is the lack of proficiency in the Russian language at all three levels: speaking, writing and professional language (Pogodaev, N.P. Zaboni rusi... 2015). In this situation there is a threat that such graduates will be pushed out into the social space of the alike outsiders. Their own reflection and the opinion of the others will be, as Bourdieu calls it, the effect of "stamping", increasing the distance effect (Bourdieu, P, 1993, p.49). In this situation they can quickly join the layers of their countrymen employed in Russia in physical labour of little prestige with further stigmatization. Such symbolic ghettoization can quickly convert into the appropriation of corresponding physical space and as the result the symbolic ghettoization turns into the physical one. The ghetto effect with great probability deprives the graduate of the social ties that are provided by the "club effect". It limits the access to the deficit resources and certain social networks. The dissonance that appears between the expectations and real abilities can lead such graduates to frustration and search for the ways "to restore social justice". Herewith, firstly, there is a search for ideologems, which transfer the responsibility from an individual to the society, and secondly, there is a search for moral support among people with the same quality of social capital, and thirdly, the attention inevitably turns to the "existing patterns". Among such patterns there is participation in organized criminal groups and radical religious organizations. The above mentioned actors, in their turn, perform active propagandistic and organizational activities to involve such outsiders into their groups.

Back in Tajikistan, this category of Russian universities graduates can probably count on a certain status rise as the owners of more prestigious Russian diplomas. But low qualification, employment difficulties associated with high levels of unemployment and the significance of parent family belonging to a particular clan, low wages and expectations of a higher level of life formed during the years of studies in Russia can create a lot of problems at home as well. Moreover, long absence from Tajikistan may also, in some cases, weaken their access to existing social lifts and deficit resources. Therefore, these young people experiencing the risks of possible symbolic ghettoization, "being deprived of all the trump cards needed to participate in various social games, can only share their excommunication" (Bourdieu, P. 1993, p. 49).

\section{Migrant Students and the Future of the Tajik Diaspora in Siberia.}

Just as Bourdieu speaks of the "concentration of the positive poles of all fields" accumulating in the capital, the concentration of positive poles of the binary culture forms the elite of the diaspora in the region recognized by ethnophors and the host community. Some students from Tajikistan who have graduated from Russian universities, will become a part of this elite. And those who came to study in 2000-2009, will become the first generation of educated Tajiks in post-Soviet Russia. The previous generation, as a rule, studied at Tomsk universities back in the Soviet years. Ethnic solidarity in case of common interests within the framework of social strategies not only provides an additional resource for different generations of the diaspora interacting with each other, not only provides a mechanism of intergenerational transmission, but also creates a synergistic effect that turns the diaspora in something more than a simple accumulation of the resources of its members. Islam will play an important role in this process as a form of religious reflection and organization of everyday practices.

The diaspora is a continuation of the social field, which connects students with their homeland and the national culture. The degree of socialization in this field may depend on the personal features of an individual, their birth 


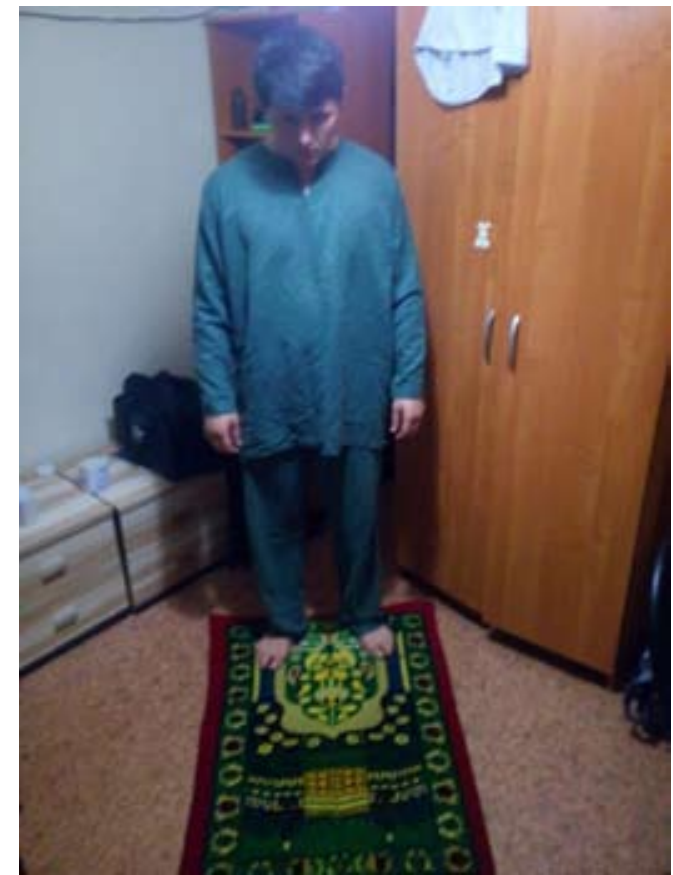

Fig. 11. Salah in the dormitory room. Facing Kaaba, standing on sajjada (carpet for praying) brought from Tajikistan

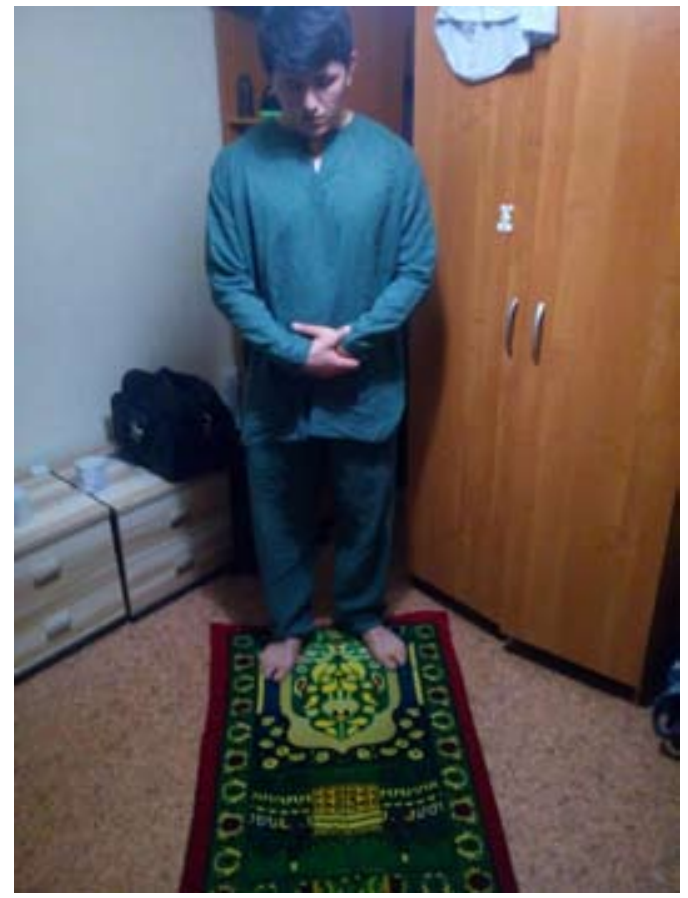

Fig. 13. Standing in Salah: both arms are placed over the chest, with the right arm over the left. Loose clothes sewed for the student by his father cover awrah - those parts of the body that should be covered during the prayer

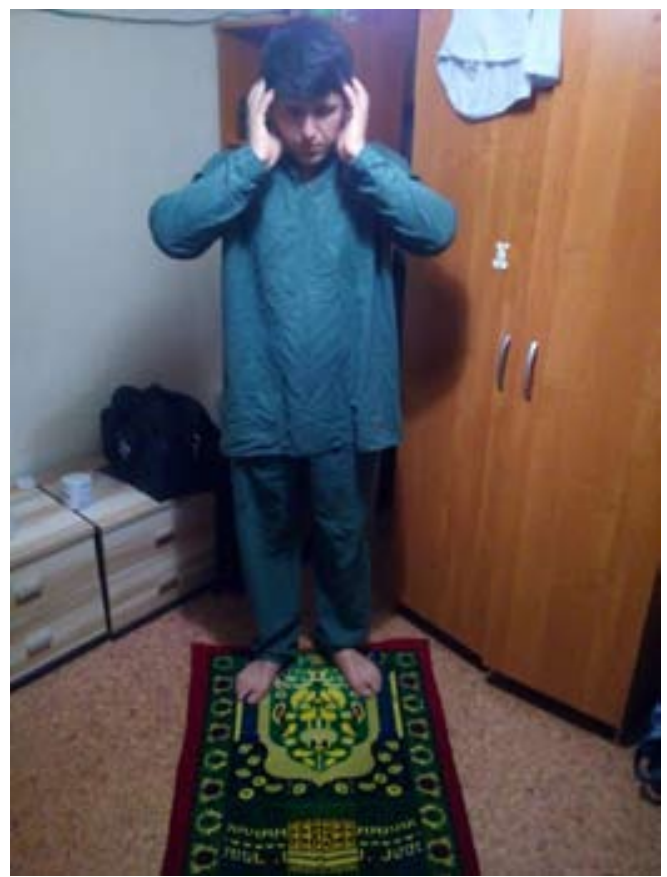

Fig. 12. Takbir. Hands towards Kaaba, big fingers at the level of earlobes

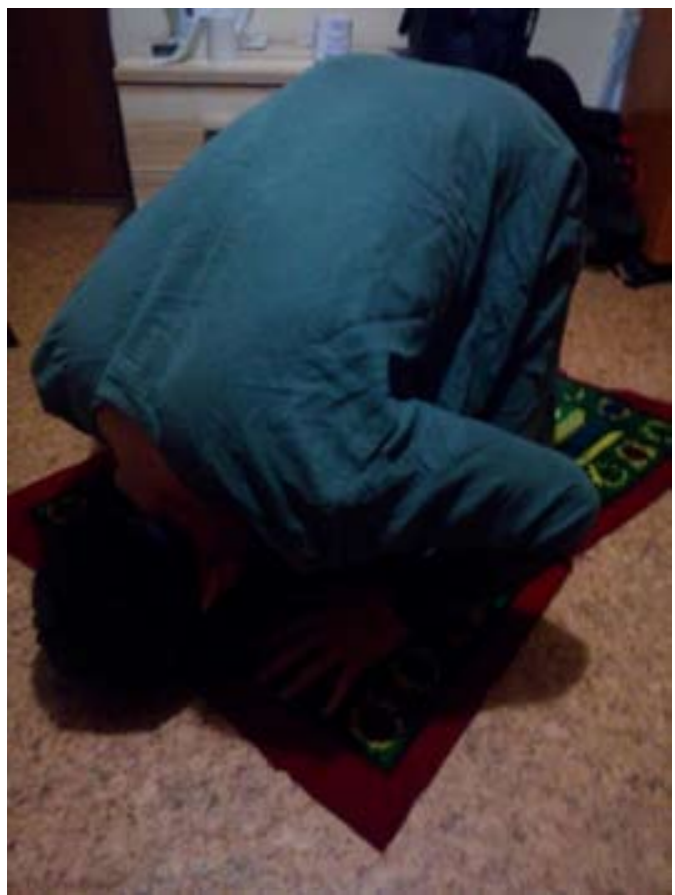

Fig. 14. Sujud: prostration 


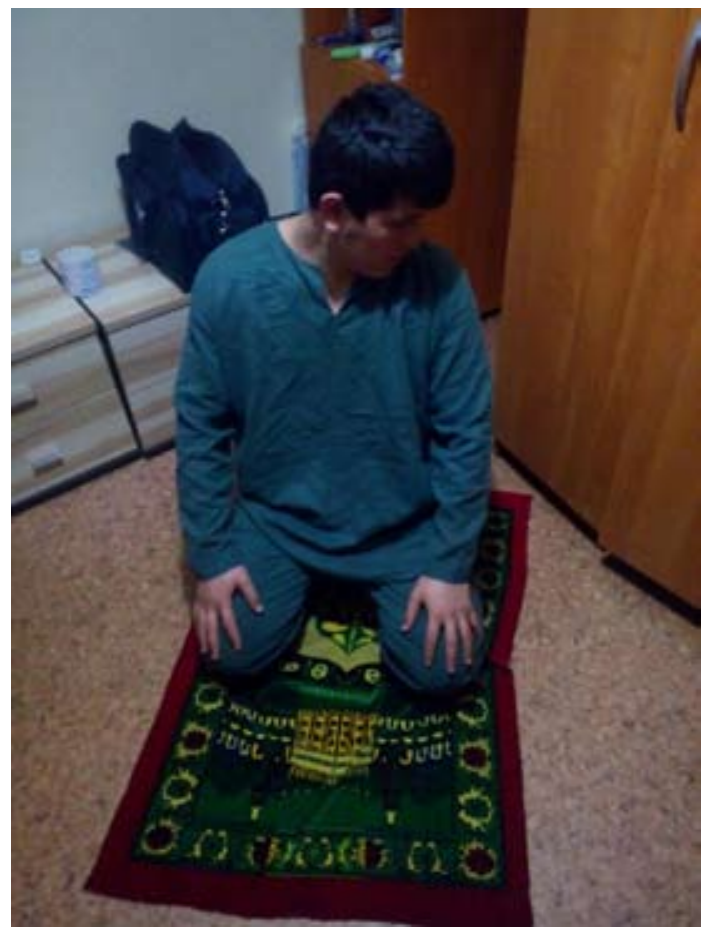

Fig. 15. The state of rest between two Sujuds

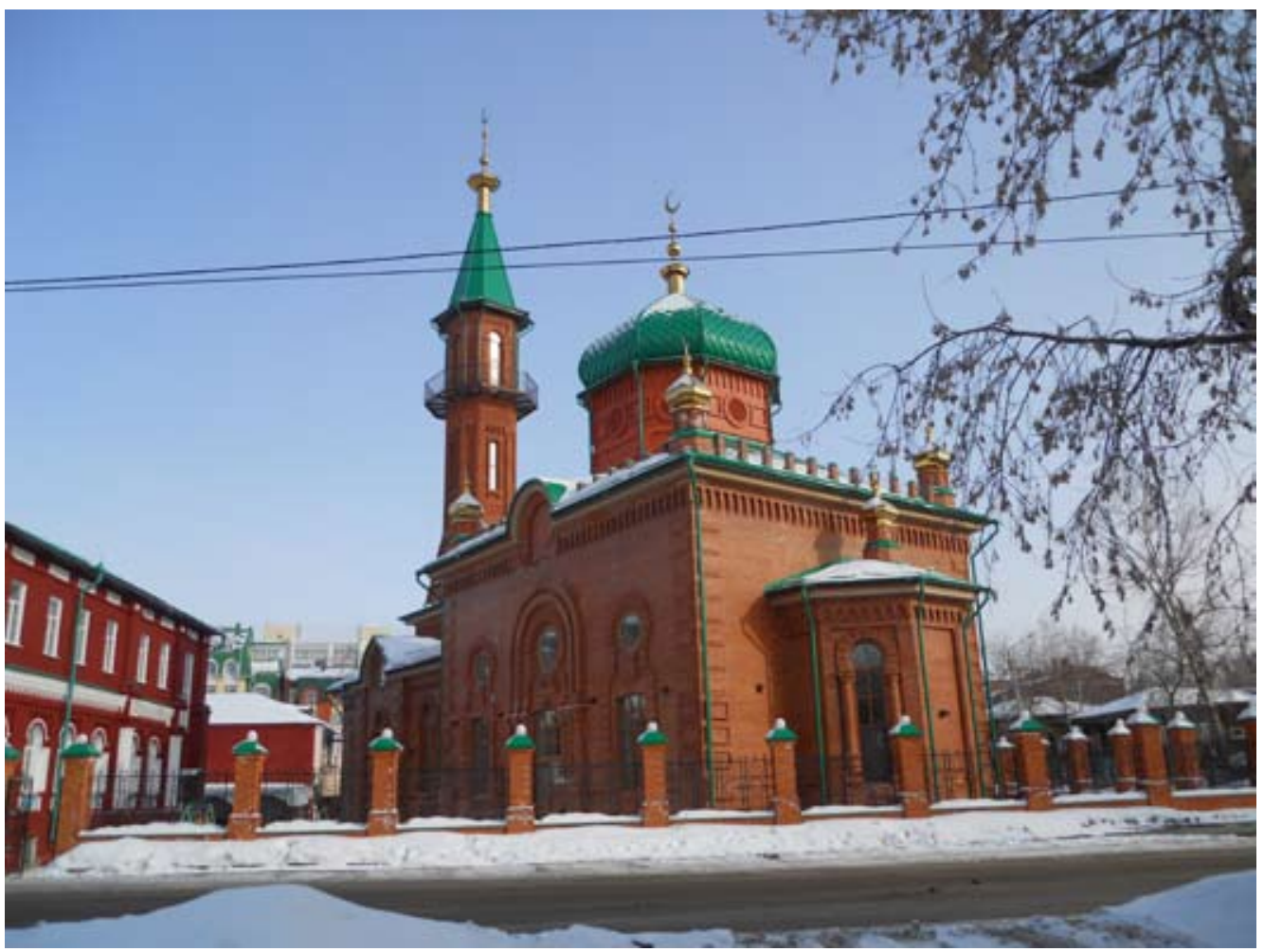

Fig. 16. The Red Mosque in Tomsk in Tatarskaya street. The Mosque's imam is Tajik. Students from Tajikistan prefer to come for Friday prayers here 
place in Tajikistan, the status of their family there, its belonging to certain territorial or clan groups. It may depend on the ability to fit in those trends that are relevant for the Tajik diaspora in the host locus of the individual's being after graduation, the interests of the most influential members of the diaspora. It is the current generation of "new Russian Asians" represented by young Tajiks with university education that will form and develop the models of enculturation of this social stratum in a multinational and multi-confessional community of Siberia and Russia as a whole. Therefore, it is important that the level of the Russian language proficiency makes them an integral part of the civil nation, and does not contain the explicit exclusion points. This problem can be solved with the help of revitalizing the preparatory departments at universities, where students from Tajikistan would be taught not only grammar and phonetics, but also lexical compatibility, multiple meanings of words and notions of Russian, where they would learn the basics of the mentality of the host community through the fictional characters and key events in the Russian history.

\section{Conclusion}

The analysis of the data of the Ministry of Education and Science shows that, firstly, the students from Tajikistan study almost all over Russia, and secondly, their amount has been gradually increasing from year to year, and thirdly, they often become students of universities in Moscow, St. Petersburg, Central Russia, the Volga region, the Ural region and Siberia. Therefore, the experience of Tomsk universities to adapt these migrant students can make a difference not only for Tomsk, but also for other university centers. Just like the experience of the latter may be interesting for Tomsk.

Those university graduates who are well adapted to the host community, gain the necessary quality of the social capital for further enculturation and become the "club members". They will bring their interpretation of the Youth Bulge phenomenon in the institutionalized form of competition for deficit social resources. Those who fall into a symbolic, and then into a physical ghetto may fulfill the destructive option of the Youth Bulge. They will be driven by unfulfilled hopes and growing frustration. The presence of even low-quality, but nevertheless higher education and related expectations can, firstly, push them to seek "social justice" through the paths of destructive activities, and secondly, provide them with leadership positions in the ghetto involving others.

The current generation of educated Tajiks will gradually replace the leaders of the Tajik diaspora, who studied at the universities of Tomsk in the days of the Soviet Union. They will ensure the model of enculturation of this social group in the multi-ethnic and multi-religious community of Tomsk and Siberia, concentrating the positive poles of their binary culture in the process of further development of the Tajik diaspora. Their environment will give rise to those who will actively participate in regional policy, especially at the municipal level. They will influence the economic and social spheres.

The presence of a significant number of people from Central Asia who have graduated from universities in Russia and remained in Russia for permanent residence, starting families here, raises the question of the need for the host community to adjust to new reality. Perception of "new Russian Asians" in Russia through the prism of ethnicity will cause intractable problems in the sphere of social control. If this emerging social category is considered not in terms of ethnicity but in terms of citizenship, they will much easier fit into the universal management model. But in this case they are required to meet the markers that are typical for the local population. One of the most important 
ones is a good command of Russian. Children of educated migrants from Tajikistan who have remained in Russia, will graduate from school already in Russia and will be enrolled in Russian universities as Russian citizens. The TajikRussian bilingualism model will give way to the Russian-Tajik one. In contrast to the patterns of their parents, intermarriage would become rather common for them. Another model related to enclavization and ghettoization of Tajiks in Russia, will lead to multiculturalism in the form of preservation of the traditional culture, national mentality, lack of knowledge of the Russian language, detachment from social lifts and existence on the periphery of the civil nation. The probability of realization of a particular model depends on many circumstances of social and political reality. In the university environment, although there is some considerable cultural distance, students from Tajikistan quickly adjust to existing conditions. But this adaptation is often relatively superficial and far insufficient for the enculturation of migrant students in the host community. The problem of the "linguistic capital" in the total capital structure, which students acquire in the host community is not the only one. Mentality and patterns that are being formed are equally important. But it is the linguistic capital that, as viewed by representatives of the host community, is the most pronounced marker of the cultural distance. One of the main challenges for universities is to develop an effective system of language study starting from the first year, which would help students from Tajikistan to take the most of the educational resource for further employment according to the degree and entering relevant social layers of the host community.

\footnotetext{
Translator's note: Питер (Piter) is a nickname for Saint Petersburg.
}

\section{References}

Beehner, L. (2007). The Effects of 'Youth Bulge' on Civil Conflicts. In Council on Foreign Relations. Available at: http://www.cfr.org/world/effects-youth-bulge-civil-conflicts/p13093

Bourdieu, P (1993). Sotsiologiia politiki [Sociology of Politics]. Translated from French. Moscow, Socio-Logos, $336 \mathrm{p}$.

Estestvennyi prirost naseleniia sub"'ektov Rossiiskoi Federatsii [Natural population growth in the subjects of the Russian Federation]. Available at: https://ru.wikipedia.org/wiki (accessed December 12, 2015).

Heinsohn, G. (2003). Söhne und Weltmacht: Terror im Aufstieg und Fall der Nationen. Zürich: Orell Füssli Verlag AG, 190 p.

Kozer, L.A. (2000). Funktsii sotsial'nogo konflikta. Per. s angl. [Functions of the Social Conflicts]. Translation from English. Moscow, Dom intellektual'noi knigi: Ideia-press. 295 p.

Knoblauch, H. (2009). Videografiia. Fokusirovannaia etnografia i videoanaliz [Videography. Focused Ethnography and Video Analysis], In Vizual'naia antropologiia: nastroika optiki [Vizual Anthropology: Optics Adjustment]. Moscow, 22.

Krasnaia mechet'v Tomske [The Red Mosque in Tomsk]. Available at: http://www.culture.ru/ institutes/12884/krasnaya-mechet-v-tomske (accessed November 12, 2015).

Kruglyi stol "Adaptatsiia migrantov - factor tsivilizovannogo obshchestva [Round Table Discussion "Migrants Adaptation: the Civilized Society Factor]. V Mezhdunarodnaia nauchnoprakticheskaia konferentsiia "Spetsifika migratsionnykh protsessov na territorii Tsentral'noi Sibiri v 
XX-XXI vekakh: opyt i perspektivy" [International Scientific Conference "Peculiarities of migration processes in Central Siberia in the $20^{\text {th }}-21^{\text {st }}$ centuries: experience and prospects"]. Siberian Federal University, Krasnoyarsk, November 30 - December 2, 2015.

Ministerstvo obrazovaniia $i$ nauki Rossiakoi Federatsii. Departament strategii, analiza $i$ prognoza [The Ministry of Education and Science of the Russian Federation. The Department of Strategy, Analysis and Forecast]. Available at http://минобрнауки.рф/министерство/статистика/ информация-2014 (accessed January 03, 2016)

Ministerstvo obrazovaniia $i$ nauki Rossiakoi Federatsii. Departament strategii, analiza $i$ prognoza [The Ministry of Education and Science of the Russian Federation. The Department of Strategy, Analysis and Forecast]. Available at: http://минобрнауки.рф/министерство/статистика/ информация-2015 (accessed January 16, 2016).

Osnovnye rezul'taty deiatel'nosti sistemy vysshego i professional'nogo obrazovaniia Tomskoi oblasti. 2015 [Main results of higher and vocational education activities in Tomsk oblast. 2015]. Available at: http://depvpo.tomsk.gov.ru/Otcheti-i-dokladi-o-deyatelynosti (accessed January 05, 2016).

Pauwels, L. (2009). Reprezentiruia dvizhushchuiusia kul'turu: problemy $i$ vozmozhnosti antropologicheskoi i sotsiologicheskoi kinos'"emki [Representing the moving culture: challenges and opportunities of anthropological and sociological filming], In Vizual'naia antropologiia: nastroika optiki [Vizual Anthropology: Optics Adjustment]. Moscow, 47.

Pogodaev, N.P. (2015). Vladenie russkim iazykom kak uslovie adaptatsii studentov-migrantov iz Tadzhikistana $v$ universitetskom prostranstve Tomska [Competence in the Russian language as a condition of adaptation of students from Tajikistan at the universities of Tomsk], In Vestnik Tomskogo gosudarstvennogo universiteta. Filosofiia. Sotsiologiia. Politologiia. [Bulletin of Tomsk State University. Philosophy. Sociology. Political Science]. 29 (1), 91-103. doi:10.17223/1998863X/29/10

Pogodaev, N.P. (2015). Zaboni rusi: problema bilingvizma iz Tadzhikistana $v$ tomskikh universitetakh [Zaboni rusi: the problem of bilinguism of Tajik students in Tomsk universities], In Migratsiia i migranty $\mathrm{v}$ Rossii i mire: opyt sotsial'no-antropologicheskikh i etnograficheskikh nabliudenii [Migration and migrants in Russia and the world: experience of anthropological and ethnographic notices]. Moscow, UEA RAN, 272.

Pogodaev, N.P. (2015). Strategiia "Keis-Stadi” pri izuchenii problem sotsial'no-kul'turnoi adaptatsii studentov iz Tadzhikistana v universitetskoi srede Tomska [Case Study Strategy During the Study of the Problems of Socio-cultural Adaptation of Student from Tajikistan in Tomsk University Space]. In Chelovek v meniaiushchemsia mire. Problemy identichnosti i sotsial'noi adaptatsii v istorii I sovremennosti [The Man in the Changing World. Problems of Identity and Social Adaptation in History and Modernity]. Izdatel'stvo Tomskogo universiteta, 232-248. doi: 10.172239785751123666/20

Pogodaev, N.P. Interv'iu TDT-4 [Interview TDT-4]. Arkhivy avtora [Author's Archives].

Pogodaev, N.P. Interv'iu TDT-6 [Interview TDT -6]. Arkhivy avtora [Author's Archives].

Pogodaev, N.P. Interv'iu STT-4.1 [Interview STT -4.1]. Arkhivy avtora [Author's Archives].

Pogodaev, N.P. Interv'iu STT-6 [Interview STT -6]. Arkhivy avtora [Author's Archives].

Pogodaev, N.P. Interv'iu STT-12 [Interview STT -12]. Arkhivy avtora [Author's Archives].

Pogodaev, N.P. Interv'iu STT-4 [Interview STT -4]. Arkhivy avtora [Author's Archives].

Pogodaev, N.P. Interv'iu STT-2 [Interview STT -2]. Arkhivy avtora [Author's Archives].

$$
-901-
$$


Pogodaev, N.P. Interv'iu STT-13 [Interview STT -13]. Arkhivy avtora [Author's Archives].

Pogodaev, N.P. Interv'iu STT-9 [Interview STT -9]. Arkhivy avtora [Author's Archives].

Pogodaev, N.P. Interv'iu STT-10 [Interview STT -10]. Arkhivy avtora [Author's Archives].

Pogodaev, N.P. Interv'iu STT-5 [Interview STT -5]. Arkhivy avtora [Author's Archives].

Pogodaev, N.P. Interv'iu STT-7 [Interview STT -7]. Arkhivy avtora [Author's Archives].

Pogodaev, N.P. Interv'iu TDKr-1 [Interview TDKr-1]. Arkhivy avtora [Author's Archives].

Reiting srednikh zarplat rabotnikov v stranakh SNG i Baltii v 2013 godu [Rating of average salaries of employees in the CIS countries and Baltics in 2013]. Available at: http://businessforecast. by/partners/ratings/1045 (accessed January 25, 2016)

Roche, S. (2014). Domesticating Youth. Youth Bulges and their Socio-political Implications in Tajikistan. Berghyhn Books, 296 p.

Spisok stran po VVP (PPS) na dushu naseleniia [The list of countries by GDP (PPP) per capita]. Available at: https://ru.wikipedia.org/wiki (accessed on December 12, 2015).

Spisok stran po urovniu rozhdaemosti [The list of countries by the birth rate]. Available at: http:// nonews.co/directory/lists/countries/birth (accessed on December 12, 2015).

Khzmalian, T. Gunnar Khainzon: Mal'chiki dlia dzhikhada [Gunnar Heinsohn: boys for jihad]. Available at: http://5165news.com/nota-bene/ (accessed December 15, 2015)

\section{Abbreviations}

STT - a student from Tajikistan (Tajik).

TDT - the leader or an active member of the Tajik diaspora in Tomsk.

$\mathrm{TDKr}$ - the leader or an active member of the Tajik diaspora in Krasnoyarsk. 


\title{
Адаптация студентов из Таджикистана \\ в университетском пространстве Томска: \\ в поисках моделей и смыслов
}

\author{
Н.П. Погодаев \\ Национальный исследовательский \\ Томский государственный университет \\ Россия, 634050, Томск, пр. Ленина, 36
}

\begin{abstract}
В последние десять лет год от года в томских университетах увеличивается количество студентов из Таджикистана. Статистика Министерства образования и науки РФ свидетельствует, что этот прочесс характерен и для других регионов России. Студентьмигранты стоят перед непростой задачей адаптации и инкультурации в принимающее сообщество. Одной из важных составляюших этого процесса является качественное овладение русским языком. Часть выпускников останется в Томске или разъедется по крупным городам Сибири, которые являются аттракторами миграционных проиессов и мультимодальными узлами миграчии. Они примут российское гражданство, создадут здесь свои семьи. Отношение к этим «новым русским азиатам» не как кмигрантам, а как к части гражданской начии усилит солидарность общества, облегчит ремение управленческих задач. Успешные социальные траектории выпускников университетов позволят направить в позитивное русло такое явление? как «Yоuth Bulge» - давление большого количества молодёжи в Таджикистане на соииально-экономическую обстановку как в стране исхода, так и в принимающем сообществе. Те, кому не удастся успешно вписаться в принимающее сообщество, могут испытать сначала символическую, а затем и физическую геттоизацию. Обманутые надежды, фрустрация могут подвигнуть их к поиску «социальной справедливости» на путях участия в преступных группировках и радикальных религиозных организациях. Индивидуальные глубинные интервью, которые являются основным методом сбора информации в рамках данного исследовательского проекта, рассматриваются с точки зрения статусов и прочих атрибутов взаимодействия респондента и интервьюера.
\end{abstract}

Ключевые слова: студенты-мигранты, культурная дистанция, культурный шок, миграиионный капитал, лингвистический капитал, Yоиth Bulge, новые pусские азиаты, индивидуальное глубинное интервью.

Статья написана в рамках проекта «Человек в меняющемся мире. Проблемы идентичности и социальной адаптации в истории и современности» (грант Правительства РФ П 220 № 14.B25.31.0009).

Елене Валентиновне Шакмарёвой с благодарностью за большую помощь.

Научная спечиальность: 22.00.00 - сочиологические науки, 24.00.00 - культурология. 